\title{
Revisiting Access to Cultural Heritage in the Public Domain: EU and International Developments
}

\author{
Andrea Wallace $\cdot$ Ellen Euler
}

Published online: 28 July 2020

(C) The Author(s) 2020

\begin{abstract}
In the past year, a number of legal developments have accelerated discussions around whether intellectual property rights can be claimed in materials generated during the reproduction of public domain works. This article analyses those developments, focusing on the 2018 German Federal Supreme Court decision Museumsfotos, Art. 14 of the 2019 Copyright and Related Rights in the Digital Single Market Directive, and relevant provisions of the 2019 Open Data and the Reuse of Public Sector Information Directive. It reveals that despite the growing consensus for protecting the public domain, there is a lack of practical guidance throughout the EU in legislation, jurisprudence, and literature on what reproduction media might attract new intellectual property rights, from scans to photography to 3D data. This leaves ample room for copyright to be claimed in reproduction materials produced by new technologies. Moreover, owners remain able to impose other restrictive measures around public domain works and data, like onsite photography bans, website terms and conditions, and exclusive arrangements with third parties. This article maps out these various legal gaps. It argues the pro-open culture spirit of the EU Directives should be embraced and provides guidance for Member States and heritage institutions around national implementation.
\end{abstract}

Keywords Copyright · Public domain - Cultural heritage organisations · Open access · DSM Directive - PSI Directive

\footnotetext{
A. Wallace $(\bowtie)$

Senior Lecturer in Law, Law School, University of Exeter, Exeter, UK e-mail: a.wallace@exeter.ac.uk

E. Euler

Professor of Information Science for Open Access and Open Data, University of Applied Science Potsdam, Potsdam, Germany

e-mail: ellen.euler@fh-potsdam.de
} 


\section{Access to Artworks in the Public Domain}

In the past year, a number of legal developments have accelerated discussions around whether intellectual property rights (IPR) can be claimed in materials produced during the reproduction of public domain works. This article analyses these developments, focusing on the 2018 German Federal Supreme Court decision Museumsfotos, ${ }^{1}$ Art. 14 of the 2019 Copyright and Related Rights in the Digital Single Market Directive (DSM Directive or DSMD), ${ }^{2}$ and relevant provisions of the 2019 Open Data and the Re-use of Public Sector Information Directive (PSI Directive or PSID). ${ }^{3}$

At the heart of this legal question lies an operational tension for cultural heritage institutions. Ensuring that public domain heritage collections are available to copy and reuse facilitates new knowledge generation and produces materials that can invigorate our creative industries. ${ }^{4}$ But digitization and open access requires institutions to take on new obligations, find new funding sources, and acquire new expertise. This increases costs at a time when government funding for the heritage sector continues to steadily decline. A claim to copyright carries its own benefits: the revenue generated from licensing reproduction media might offset these digitization expenses. Moreover, new business models built around new digital media can support day-to-day operational costs. Herein lies the long-standing international legal and ethical debate: are heritage institutions justified in claiming copyright in reproductions of public domain works to generate much needed revenue, or do such restrictive measures conflict with educational missions and the rationale supporting a robust public domain?

While questions around IPR have long dominated this area, this article takes a holistic approach to how access is defined by overlapping legal and policy measures. Indeed, access is (at least) a two-part consideration involving policies around not only access and reuse of the digital collection, but also the material collection. From an institutional perspective, various issues must be considered from the safety of the work onsite to the preservation of its educational context online, and from concerns around digital asset management and revenue generation to the level of open access (or not) desired by the institution. Thus, access to material and digital heritage in the public domain may be defined by more than one parameter. This reality transfers to respective legal questions: access restrictions often engage with multiple parameters in contract, property, or intellectual property law. Viewing the question of IPR in isolation allows us to weigh the legality of a copyright claim, but it ignores other access barriers that might resemble or achieve the same result.

Accordingly, we seek to place recent EU legal developments within their wider practical context. We begin by focusing on IPR at the most basic level:

\footnotetext{
${ }^{1}$ German Federal Supreme Court, 20 December 2018, Case No. I ZR 104/17 - Museumsfotos (REM $I V(c))$, available at https://perma.cc/Q68G-EKPR.

${ }^{2}$ Directive (EU) 2019/790 of the European Parliament and of the Council 17 April 2019 on copyright and related rights in the Digital Single Market amending Directives 96/9/EC and 2001/29/EC OJ L 130/92, Art. 14.

${ }^{3}$ Directive (EU) 2019/1024 of the European Parliament and of the Council of 20 June 2019 on open data and the re-use of public sector information (recast) OJ L 172/56.

${ }^{4}$ Peukert (2012), para. 113.
} 
photographic reproductions of two-dimensional artworks. In Sect. 2, we lay out key cases leading up to the 2018 litigation brought by the Reiss Engelhorn Museum in Germany (REM or the Museum) - a decision that not only recognized IPR in photographic reproductions of public domain artworks, but also validated the Museum's onsite restrictions on visitor photography. Section 3 analyses the wider challenges to access raised by the REM decision (REM Caselaw) ${ }^{5}$ We then consider EU policy around open culture in Sect. 4, as well as the questions posed by the revised DSM and PSI Directives. Finally, Sect. 5 explores potential resistance to legal reform by alleged rightsholders, as well as how transposition might counter resistance while allowing for growth in technological innovation.

In doing so, we take a comprehensive approach to analysing the doctrinal questions underlying copyright in addition to operational issues informing institutions' policies. ${ }^{6}$ The article reveals that despite the growing legal consensus around protecting the public domain, gaps in law, policy, and practice provide leeway for institutions (and other actors) to maintain the status quo of claiming copyright in reproductions and restricting access via other measures. Institutions are already cash-strapped, and the private sector is heavily invested in the market for reproduction media. Despite the difficulties ahead, we argue the pro-open culture spirit of legal developments should be embraced by Member States during transposition and heritage institutions revising IP policies. We conclude by exploring not only how, but why.

\section{International Perspectives on IPR in Photographic Reproductions}

To understand the current state of international perspectives, we first consider the historical and global context. ${ }^{7}$ Only a handful of courts have considered this issue with mixed results. ${ }^{8}$ Key decisions include Graves' Case (UK in 1869), ${ }^{9}$ Bridgeman Art Library v. Corel (Bridgeman I and Bridgeman II) (USA in 1998 and 1999), ${ }^{10}$

\footnotetext{
5 These cases are collectively referred to as REM Caselaw, discussed in Sect. 3.

6 This article includes extensive references to aid understanding in this area.

7 Whether and how copyright arises is influenced by international treaties, national legislation, judicial interpretation, or the photographer's choices. Historically, distinctions have been made between "sweat of the brow" jurisdictions and those requiring creativity or personality for copyright. Rahmatian (2013), pp. 5-6. Over the years, international copyright trends and globalization have shepherded an emerging consensus for focusing on creative choices, however minor. See Gervais (2002); see also Margoni (2016).

8 See Margoni (2014). One reason the issue remains unsettled is the reluctance to bring suit. The less public and more efficient approach is to send cease-and-desist notices. Tanner (2004), pp. 29-30. One example includes the National Portrait Gallery's dispute with Wikipedia editor Derrick Coetzee. In addition to copyright, questions arose around the binding nature of the website's terms and the technological measures used to circumvent the Zoomify software to download images. Because the case never went to trial, these questions remain unanswered. See "User:Dcoetzee/NPG Legal Threat Wikimedia Commons" (Wikimedia, 10 July 2009), available at https://perma.cc/DE2Y-34KF; Petri (2014), pp. 1-2.

9 Graves' Case [1869] LR 4 QB 715.

${ }^{10}$ Bridgeman Art Library, Ltd v. Corel Corp (Bridgeman I), 25 F. Supp. 2d 421 (S.D.N.Y. 1998); Bridgeman Art Library, Ltd v. Corel Corp (Bridgeman II), 36 F. Supp. 2d 191 (S.D.N.Y. 1999).
} 
and Museumsfotos (Germany in 2018). ${ }^{11}$ A related decision concerning portrait photography is Eva-Maria Painer v. Standard Verlags GmbH (CJEU in 2011). ${ }^{12}$ Each decision contains shortcomings when considered against technological advancements.

Perhaps the most significant imperfection is that all four cases litigated outdated reproduction methods. This raises at least two issues. First, photographic technologies have made significant strides since 2011, let alone since 1999 and 1869 - yet we have little guidance around IPR and digital methods of reproduction. ${ }^{13}$ Even the 2018 REM Caselaw decision assessed analogue photography. ${ }^{14}$ Thus, grey areas remain around copyright in reproductions produced by new technologies, from digital scans to photography to 3D data, especially if postproduction digital editing occurs.

Second, the three cases about artwork reproductions conflate the layers of reproduction and potential copyrights in the final output. ${ }^{15}$ Because an output may sustain multiple format transfers, or select components of the output, like descriptive metadata or professionally-reconstructed areas, might attract copyright, rights could apply to only certain layers or portions of the output, rather than the image (or raw data) itself. ${ }^{16}$ These rights may be improperly claimed or misstated in the final output. ${ }^{17}$ Below, we analyse the prior caselaw to frame these various drawbacks when applied to contemporary issues.

The issue of copyright in artwork reproductions dates back to a 1869 dispute. ${ }^{18}$ In Graves' Case, Judge Blackman considered copyright in a photograph of an incopyright engraving of a painting, and held the reproduction was original. ${ }^{19}$ More than a century later, in 1998, the issue came before a United States District Court in Bridgeman Art Library v. Corel Corp with an opposite outcome. Judge Kaplan considered the originality of a photographic transparency of an artwork with (at least) one important distinction: the underlying works were in the public domain. ${ }^{20}$ Highlighting the antiquity of Graves' Case and subsequent developments in

11 REM IV $(c)$ in Sect. 3.

12 CJEU, 1 December 2012, C-145/10 Eva-Maria Painer v. Standard Verlags GmbH and Others.

13 Discussed in Sect. 3.

14 Copyright in Praefcke's digital photographs was not considered in REM IV $(A-C)$.

15 For Graves' Case, the output was (1) analogue photograph of an (2) engraving of a (3) painting; for Bridgeman, the output was (1) digital scan of an (2) analogue photographic transparency of a (3) painting; for REM Caselaw the outputs were (a) a (1) digital scan of a (2) analogue photograph printed in a catalogue of a (3) painting, and (b) a (1) digital photograph of a (2) painting.

16 Wallace (2016), pp. 9-27; (2019), pp. 25-39.

17 See Judith Blijden, "Research Paper: The Accuracy of Rights Statements on Europeana.eu" (Kennisland, 2018), available at https://perma.cc/2QNR-CB8B.

18 Fine Arts Copyright Act 1862, 25 and 26 Vict. (c. 68).

19 The defendant contested originality, arguing the photographs were "mere copies". [1869] LR 4 QB 715, p. 720. ("The distinction between an original painting and its copy is well understood, but it is difficult to say what can be meant by an original photograph. All photographs are copies of some object, such as a painting or statue. And it seems to me that a photograph taken from a picture is an original photograph, in so far as to copy it is an infringement of this statute.").

${ }^{20}$ Due to exclusive contracts with the owners, Bridgeman argued Corel could only have obtained the images by digitizing Bridgeman's transparencies. Bridgeman I, 25 F. Supp. 2d 421, p. 424. 
originality, Judge Kaplan held the photographic reproductions to be non-original under both $\mathrm{UK}^{21}$ and $\mathrm{US}^{22}$ copyright law because the contested photographs slavishly reproduced the underlying works. ${ }^{23}$

Naturally, copyright advocates have zealously defended Graves' Case ${ }^{24}$ while open access advocates have stood staunchly behind the Bridgeman doctrine. ${ }^{25}$ But these cases have limited binding effect. First, while Graves' Case has not been overturned, scholars contest its application to contemporary originality. ${ }^{26}$ Many posit the in-copyright status of the underlying engraving may have influenced the outcome and question its usefulness against modern technologies. ${ }^{27}$ Second, although the Bridgeman doctrine is widely cited, the decision binds only the Southern District of New York and was (until recently) largely ignored by its cultural institutions. ${ }^{28}$ Bridgeman's greater impact was to stimulate international institutional discussions on open access over the next two decades.

In the EU, discussions turn to a 2011 CJEU decision involving portrait photography. In Eva Marie Painer v. Standard VerlagsGmbH, the CJEU considered whether portrait photography could satisfy the EU originality standard of the "author's own intellectual creation" (AOIC). ${ }^{29}$ Arguments against had advanced that the work's predetermined subject matter (i.e. the person featured) rendered any remaining choices insufficient to warrant protection. The CJEU disagreed, reasoning the freedom available to make "free and creative choices" could occur

\footnotetext{
${ }_{21}$ Bridgeman I, 25 F. Supp. 2d 421, p. 426.

22 Bridgeman II, 36 F. Supp. 2d 191, p. 197. It is worth noting that same year, the Polish Supreme Court issued a similar outcome based on copyright and contract law, building on a 1995 Court of Appeals case also supporting a non-original status. See Margoni (2014), pp. 43-44 (citing Polish Supreme Court, 27 June 1998, I PKN 196/98 and Court of Appeal, Warsaw, 5 July 1995, I Acr 453/94).
}

${ }^{23}$ Bridgeman I, 25 F. Supp. 2d 421, p. 426; Bridgeman II, 36 F. Supp. 2d 191, p. 195.

${ }^{24}$ See, e.g. Garnett (2000); Stokes (2001); Wienand et al. (2000), pp. 56-59; Johnathan Rayner James, QC, "Copyright in Photographs of Works of Art" (Museums Copyright Group, 2006), available at https:// perma.cc/722V-YRT8; Comments by Harriet Bridgeman in Tom Morgan, "Wikipedia and the National Portrait Gallery - A bad first date?" GLAM-WIKI 2010 - Wikimedia UK (Wikipedia, 2010), 00:54:00 to 00:57:00, available at https://wikimedia.org.uk/wiki/GLAM-WIKI_2010 (Accessed 21 August 2019).

${ }^{25}$ See, e.g. Deazley (2001); Hamma (2005); Butler (1998); Cameron (2006); Schmidt (2017).

${ }^{26}$ See Garnett (2000); Deazley (2001); Stokes (2001); Stokes (2002).

27 Deazley (2001), p. 179; Petri (2014), p. 4. In 2012, a UK court examined the EU ("author's own intellectual creation") and UK ("skill, labour, and/or judgement") copyright standards and found "no difference in substance" between the law as applied by the Austrian Supreme Court, the CJEU, and UK courts "if the task of taking the photograph leaves ample room for individual arrangement." Temple Island v. New English teas and Nicholas John Houghton [2012] EWPCC 1, para. 20. See also Bently et al. (2018), pp. 112-117.

${ }^{28}$ Most SDNY institutions, including the Guggenheim and Museum of Modern Art, continue copyright claims. In 2016, the New York Public Library adopted the Public Domain Mark; in 2017, the Metropolitan Museum of Art adopted the Creative Commons CCO dedication. Outside of SDNY, Bridgeman was cited by the 10th Circuit in Meshwerks, Inc v. Toyota Motor Sales USA, Inc, 528 F.3e 1258 (10th Cir. 2008), p. 1258. In 2016, a New Mexico District Court extended its logic to 2D reproductions of 3D works when the photographer's choices are "utilitarian" and "made to best copy the three dimensional artefact." President and Fellow of Harvard College v. Steve Elmore, No. CIV 15-00472-RB/KK (D.N.M. 2016), p. 19.

${ }^{29}$ Directive 2011/116/EC of the European Parliament and of the Council of 12 December 2006 on the term of protection of copyright and certain related rights OJ L 372, Art. 6. 
during various stages of production: ${ }^{30}$ preparation, when the photographer chooses the background, subject's pose, and lighting; ${ }^{31}$ capture, when the photographer might choose the framing, angle of view, and atmosphere created; ${ }^{32}$ or printing, when the photographer might select the desired image and apply a range of developing techniques or editing software. ${ }^{33}$ Through these choices, "the author of the portrait photograph can stamp the work created with his "personal touch." 34

Although it does not address our specific question, the 2011 CJEU Painer opinion preserves the possibility for decisions to attract copyright during artwork reproduction. Like portraits, the subjects of reproductions are also predetermined, but cannot be excluded on this basis alone or because any remaining choices are limited. Still, the photographer's personal touch must be imprinted on the work. ${ }^{35}$

Seven years later, in 2018, the Federal Supreme Court in Germany considered this spectrum of choices against photographic reproductions of public domain paintings made in 1992. The REM had launched a wave of actions against defendants who used reproductions made available on Wikimedia Commons. The Federal Supreme Court held although the REM's photographic reproductions were not original under the harmonised EU standard, they did attract a related EU protection for non-original "other photographs" transposed in the German Copyright Act. ${ }^{36}$

While REM Caselaw provides some copyright clarity, it leaves open other questions around property law and persuasive impact on other jurisdictions. ${ }^{37}$ The Court's validation of visitor photography bans adds a layer when considering access obligations of public institutions and the complex nature of exclusion, both onsite and online. Consequently, these key cases guide the international debate, with each imperfect in its own way.

Recent EU legislation seeks to clarify the necessary IPR status for reproduction media. Published on 17 April 2019, Art. 14 of the DSM Directive states that no new rights can be claimed in material generated during acts of reproduction unless the author's own intellectual creation standard is met. ${ }^{38}$ Article 14 is designed to put an

\footnotetext{
30 CJEU, 1 December 2012, C-145/10 Eva-Maria Painer v. Standard Verlags GmbH and Others, paras. 93-98.

31 Ibid, paras. 90-91.

32 Ibid, paras. 90-91.

33 Ibid, paras. 90-91.

34 Ibid, para. 92.

35 Since Painer, the CJEU has stressed "significant labour and skill ... cannot as such justify [copyright] protection if they do not express any originality." CJEU, 1 March 2012, C-604/10 Football Dataco and Others v. Yahoo! UK Ltd and Others, para. 53(1).

${ }^{36}$ REM IV (c), paras. 21-27. Article 72(1) of German Act on Copyright and Related Rights (Copyright Act) (Urheberrechtsgesetz - UrhG) transposes the EU Art. 6 "other photographs" protection into national law. "Lichtbilder und Erzeugnisse, die ähnlich wie Lichtbilder hergestellt werden, werden in entsprechender Anwendung der für Lichtbildwerke geltenden Vorschriften des Teils 1 geschützt" (UrhG) § 72(1); Directive 2006/116/EC, Art. 6.

37 Discussed in Sect. 2.

38 Directive (EU) 790/2019, Art. 14, Recital 53.
} 
end to owners making improper claims in reproduction media of public domain artworks, but there are some important limitations. ${ }^{39}$ And whether IPR arises is only one link in the access chain. As discussed above, other measures may shape how access is extended to digital and material public domain works, like onsite photography bans, website terms and conditions (T\&Cs), and contractual arrangements with third parties. ${ }^{40}$ This is why ambiguities in national laws and gaps in the 2019 PSI Directive must also be considered. ${ }^{41}$

Against this backdrop, Sect. 3 explores the legal uncertainties illustrated by REM Caselaw - especially the effect of dual restrictions on access to public domain works.

\section{REM Caselaw and the Two-Part Problem}

The conflict began in 2015 when the REM (represented by the city of Mannheim) brought suit against the Wikimedia Foundation and Wikimedia Deutschland for hosting 37 photographic reproductions of artworks in the Museum's collection (Table 1). ${ }^{42}$ Seventeen images had been taken in 1992 by an REM photographer and printed in an exhibition catalogue. Wikipedia user and editor Andreas Praefcke scanned and uploaded these images to Wikimedia Commons, along with 20 of his own photographic reproductions made during a 2007 visit. All images had been marked public domain and were downloaded and reused by various users. For this, REM brought a separate claim against Andreas Praefcke. ${ }^{43}$ Due to the case's importance for Wikimedia and its users, the German chapter provided Praefcke's defence. ${ }^{44}$ At the same time, REM filed proceedings against other users who downloaded the images and used them online. ${ }^{45}$

The REM was successful in almost every proceeding except in the Local Court of Nürnberg (REM I), which denied protection based on a teleological interpretation. In other words, protecting photographic reproductions and photography bans would undermine public freedom, install perpetual copyright, and eliminate reuse of the public domain. ${ }^{46}$ REM IV $(c)$ invalidated this reasoning. ${ }^{47}$ Both REM III and REM IV went as far as the Federal Supreme Court.

\footnotetext{
39 Discussed in Sect. 4.

40 See, e.g. Crews (2012); Crews and Brown (2011). See also Pierre Noual, "Photographier au Musée: Guide de sensibilisation juridique à l'usage du visiteur-photographe," (2017), available at https://perma. cc/ZE93-AQ6Z; Katyal (2017), p. 1114.

41 Discussed in Sect. 4.

42 Table 1, REM III $(a-c)$; "Category: Images Subject to Reiss Engelhorn Museum Lawsuit" (Wikimedia Commons), available at https://perma.cc/VAA4-YG3K.

43 Table 1, REM IV $(a-c)$.

44 Comments made by Andreas Praefcke (defendant) and John Weitzmann (Counsel for Wikimedia).

45 Table 1, REM I(1-2) and REM II.

46 See $R E M I(1)$, paras. 15-17.

47 REM IV (c), para. 30.
} 
Table 1 REM Caselaw

\begin{tabular}{|c|c|c|c|c|}
\hline Case & Description & Image(s) & Outcome & Legal result \\
\hline $\begin{array}{l}\text { (REM I) } \\
\text { (1) Local Court } \\
\text { Nürnberg, } 28 \\
\text { October } \\
\text { 2015, Case } \\
\text { No. 32 C } \\
\text { 4607/15, and } \\
\text { (2) Local Court } \\
\text { Nürnberg, } 22 \\
\text { October } 2016 \\
\text { Case No. } 32 \\
\text { C 4607/15 }\end{array}$ & $\begin{array}{l}\text { REM (represented by } \\
\text { Mannheim) } \\
\text { claimed damages } \\
\text { for copyright } \\
\text { infringement from } \\
\text { a user who } \\
\text { downloaded a } \\
\text { Wikimedia } \\
\text { Commons file and } \\
\text { made it available } \\
\text { on his own website }\end{array}$ & $\begin{array}{l}\text { Portrait of Richard- } \\
\text { Wagner, c. 1862, oil } \\
\text { on canvas, Caesar } \\
\text { Willich } \\
(1825-1886)\end{array}$ & $\begin{array}{l}\text { REM } \\
\text { defeated } \\
\text { and } \\
\text { ordered to } \\
\text { pay all } \\
\text { trial and } \\
\text { pre-trial } \\
\text { costs }\end{array}$ & $\begin{array}{l}\text { Denial of Sec. 2(2) } \\
\text { No. } 5 \text { Copyright Act } \\
\text { "original" } \\
\text { photograph and Sec. } \\
72 \text { Copyright Act } \\
\text { "simple light } \\
\text { photograph" rights } \\
\text { in REM photos due } \\
\text { to teleological } \\
\text { interpretation } \\
\text { Invalidated by the } \\
\text { Federal Supreme } \\
\text { Court decision }\end{array}$ \\
\hline $\begin{array}{l}(\text { REM II }) \\
\text { District Court } \\
\text { Berlin, } 19 \\
\text { May 2015, } \\
\text { Case No. } 16 \\
\text { O } 175 / 15\end{array}$ & $\begin{array}{l}\text { REM (represented by } \\
\text { Mannheim) } \\
\text { claimed injunctive } \\
\text { relief against a } \\
\text { New York photo } \\
\text { agency that } \\
\text { downloaded a } \\
\text { Wikimedia } \\
\text { Commons file and } \\
\text { offered it for sale } \\
\text { online }\end{array}$ & $\begin{array}{l}\text { Portrait of Richard- } \\
\text { Wagner, c. 1862, oil } \\
\text { on canvas, Caesar } \\
\text { Willich } \\
(1825-1886)\end{array}$ & $\begin{array}{l}\text { REM } \\
\text { successful } \\
\text { Defendant } \\
\text { ordered to } \\
\text { pay all } \\
\text { trial and } \\
\text { pre-trial } \\
\text { costs }\end{array}$ & $\begin{array}{l}\text { Denial of Sec. 2(2) } \\
\text { No. } 5 \text { Copyright Act } \\
\text { "original" } \\
\text { photographs, but } \\
\text { recognition of Sec. } 72 \\
\text { Copyright Act } \\
\text { "simple light } \\
\text { photograph" rights } \\
\text { in REM photos }\end{array}$ \\
\hline $\begin{array}{l}\text { (REM III) } \\
\text { (a) District } \\
\text { Court Berlin, } \\
31 \text { May 2016, } \\
\text { Case No. 15 } \\
\text { O 428/15 } \\
\text { Appeal } \\
\text { (b) Court of } \\
\text { Appeal } \\
\text { Berlin, } 8 \\
\text { November } \\
\text { 2017, Case } \\
\text { No. 24 U } \\
\text { 125/16 } \\
\text { Appeal for non- } \\
\text { admission } \\
\text { (c) Federal } \\
\text { Supreme } \\
\text { Court, 12 } \\
\text { February } \\
\text { 2019, Case } \\
\text { No. I ZR } \\
189 / 17\end{array}$ & $\begin{array}{l}\text { REM (represented by } \\
\text { Mannheim) } \\
\text { claimed injunctive } \\
\text { relief against the } \\
\text { Wikimedia } \\
\text { Foundation and } \\
\text { Wikimedia } \\
\text { Deutschland for } \\
\text { hosting REM's } \\
\text { photographic } \\
\text { reproductions }\end{array}$ & $\begin{array}{l}17 \text { images by REM } \\
\text { photographers in } \\
\text { 1992, scanned and } \\
\text { uploaded to } \\
\text { Wikimedia } \\
\text { Commons by } \\
\text { Praefcke }\end{array}$ & $\begin{array}{l}\text { REM } \\
\text { successful } \\
\text { Defendant } \\
\text { ordered to } \\
\text { pay all } \\
\text { trial and } \\
\text { pre-trial } \\
\text { costs }\end{array}$ & $\begin{array}{l}\text { Recognition of Sec. } \\
72 \text { Copyright Act } \\
\text { "simple light } \\
\text { photograph" rights } \\
\text { in REM photos } \\
\text { On appeal, the Court } \\
\text { of Appeal (KG) } \\
\text { upheld the decision. } \\
\text { A second appeal } \\
\text { was not allowed, } \\
\text { and the non- } \\
\text { admission appeal } \\
\text { was rejected by the } \\
\text { Federal Supreme } \\
\text { Court after ruling } \\
\text { on the merits in the } \\
\text { parallel proceeding, } \\
\text { REM IV(c) }\end{array}$ \\
\hline
\end{tabular}


Table 1 continued

\begin{tabular}{|c|c|c|c|c|}
\hline Case & Description & Image(s) & Outcome & Legal result \\
\hline $\begin{array}{l}\text { (REM IV) } \\
\text { (a) District } \\
\text { Court } \\
\text { Stuttgart, } 27 \\
\text { September } \\
\text { 2016, Case } \\
\text { No. 17 O } \\
\text { 690/15 } \\
\text { Appeal } \\
\text { (b) Court of } \\
\text { Appeal } \\
\text { Stuttgart, 31 } \\
\text { May 2017, } \\
\text { Case No. } 4 \text { U } \\
\text { 204/16 } \\
\text { Appeal } \\
\text { (c) Federal } \\
\text { Supreme } \\
\text { Court, 20 } \\
\text { December } \\
\text { 2018, Case } \\
\text { No. I ZR } \\
\text { 104/17 }\end{array}$ & $\begin{array}{l}\text { REM (represented by } \\
\text { Mannheim) claimed } \\
\text { injunctive relief } \\
\text { against Andreas } \\
\text { Praefcke for } \\
\text { scanning and } \\
\text { uploading REM's } \\
\text { photographic } \\
\text { reproductions, and } \\
\text { for capturing and } \\
\text { uploading his own } \\
\text { photographic } \\
\text { reproductions }\end{array}$ & $\begin{array}{l}17 \text { images by REM } \\
\text { photographers in } \\
\text { 1992, scanned and } \\
\text { uploaded to } \\
\text { Wikimedia } \\
\text { Commons by } \\
\text { Praefcke } \\
20 \text { images by Prafcke } \\
\text { in } 2007 \text {, uploaded to } \\
\text { Wikimedia } \\
\text { Commons by } \\
\text { Praefcke }\end{array}$ & $\begin{array}{l}\text { REM } \\
\text { successful } \\
\text { Defendant } \\
\text { ordered to } \\
\text { pay all } \\
\text { trial and } \\
\text { pre-trial } \\
\text { costs }\end{array}$ & $\begin{array}{l}\text { Recognition of Sec. } \\
72 \text { Copyright Act } \\
\text { "simple light } \\
\text { photograph" rights } \\
\text { in REM photos, and } \\
\text { Praefcke's photos } \\
\text { violate the visitor } \\
\text { contract } \\
\text { On appeal, the verdict } \\
\text { is upheld by the } \\
\text { Higher Regional } \\
\text { Court and the } \\
\text { Federal Supreme } \\
\text { Court }\end{array}$ \\
\hline
\end{tabular}

REM I(1), available at https://oj.is/864917 (Accessed 1 October 2019)

REM I(2), available at https://openjur.de/u/892241.html (Accessed 1 October 2019)

REM II (no text available online)

REM III(a) (Schutzfähigkeit einer Lichtbildkopie eines gemeinfreien Werkes - Reproduktionsfotografie), available at https://perma.cc/8LEW-P8W4 (jpg) and https://perma.cc/7Q7P-R6QU (text)

REM III(b) (Zum urheberrechtlichen Leistungsschutz bei Reproduktionsfotografien), ECLI:DE:KG:2017:1108.24U125.16.0A, BeckRS 2017, 142191 (no text available online)

REM III(c) (Rechtsfrage bereits geklärt - Fotografien unterfallen dem urheberrechtlichen Lichtbildschutz), available at https://perma.cc/PC7B-J6R7

REM IV(a) (Lichtbildschutz für Gegenstands- und Reproduktionsfotografie), available at https://perma.cc/ 2EBW-HQF3

REM IV(b) (Schutz von Reproduktionsfotografien gemeinfreier Kunstwerke - Reiss-Engelhorn-Museen), available at https://perma.cc/PEC8-CPZU

REM IV(c) (Museumsfotos), available at https://perma.cc/XW8J-7AVX

\subsection{Main Proceeding: REM IV(c) Against Andreas Praefcke}

Two issues were of importance in REM IV(c). The first concerns the copyright status of the 17 Museum photographs made in 1992 (Fig. 1, following pages). German copyright law distinguishes between the protection of "original" photographs as Sec. 2(1) No. 5 Copyright Act works (the Art. 6 AOIC standard) and Sec. 72 "simple light" photographs lacking originality (the Art. 6 "other photographs" protection). ${ }^{48}$ Rather

\footnotetext{
${ }_{48}$ See Directive 2006/116/EC, Art. 6.
} 


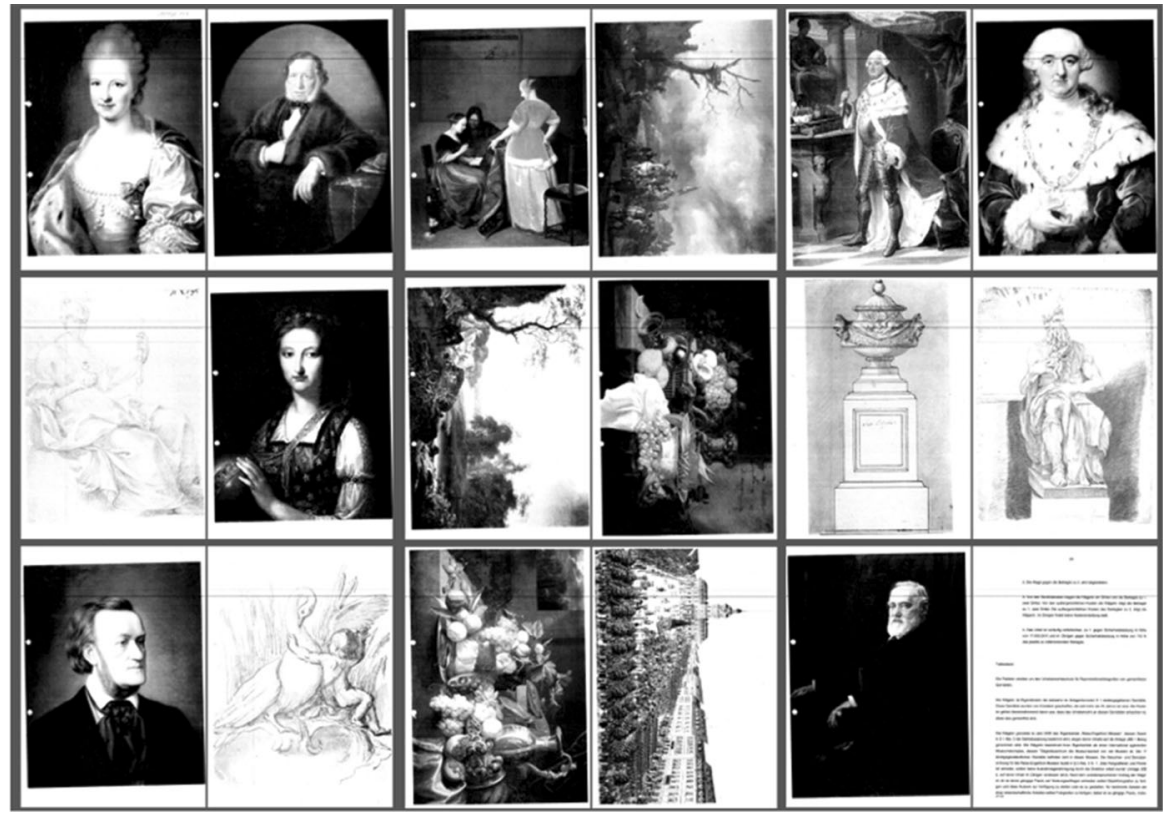

Fig. 1 Screenshots of pages 3-20 from REM III(a)

than the full copyright term of "life plus seventy years," Sec. 72 works are protected for 50 years after publication. ${ }^{49}$ This protection also encompasses "products manufactured in a similar manner to photographs," 50 such as $3 \mathrm{D}$ models made by photogrammetry.

The REM argued its photographs were sufficiently original. While the lower courts in REM II-IV evaluated protection under Sec. 72 Copyright Act, ${ }^{51}$ only REM III ( $a$ ) evaluated whether Sec. 2(2) Copyright Act creativity was met. ${ }^{52}$ There, the Regional Court of Berlin determined the Museum's reproductions fell short because the photographer's freedom was limited to a technically-clean implementation of the task of producing a faithful representation, ${ }^{53}$ which satisfied only the minimum level of "personal intellectual achievement" recognised Sec. 72 Copyright Act. ${ }^{54}$ On appeal, the Federal Supreme Court similarly reasoned such photographs constitute a "dimension shifting" of the source work to a different format (i.e.

\footnotetext{
${ }^{49}$ When the photos were taken in 1992, Sec. 72 Copyright Act's term of protection was for 25 years after publication (See UrhG BGB1. I Nr. 33, 27.6.1985, p. 1137). A 1995 revision of the act extended this period to 50 years (See UrhG BGB1. I Nr. 32, 29.06.1995, p. 843), including for Sec. 72 works in which the rights had not yet expired (Sec. 137f(1) sentence 2 Copyright Act).

50 Sec. 72(1) Copyright Act.

51 See $R E M I V(a)$, para. 13 and $R E M I V(b)$, para. 55; but see $R E M I V(b)$, para. 56, stating protection appears unlikely considering there is no room for creative freedom in faithful reproductions.

52 REM III (a), paras. 30-64.

53 REM III(a), paras. 31-33.

54 REM III(a), paras. 34-49.
} 
analogue to digital conversion). ${ }^{55}$ Although made with a purpose akin to copying, ${ }^{56}$ the Court held the ability to select the location, distance, angle, exposure, and cropping were technical choices warranting Sec. 72 Copyright Act protection. ${ }^{57}$ The Federal Supreme Court reasoned this right prevails even when the photographer operates within a reduced scope of decisions dictated by technical settings or other limitations via the technology used. ${ }^{58}$ Consequently, photographic reproductions of paintings in Germany are neither copies nor original works, but something in between. ${ }^{59}$ The result is that using photographic reproductions without permission violates Sec. 72(1) Copyright Act.

The second issue concerns the 20 photographs taken personally by Praefcke in 2007. Onsite, the Museum clearly banned visitor photography, as indicated by a pictograph with a crossed-out camera on visitor regulation signs. At issue was whether Praefcke's photographs breached the visitation contract supported by the Museum's ownership of the artworks and rights in rem. Praefcke's defence relied on tensions between the German Civil Code (BGB) and fundamental rights guaranteed by constitutional law. This required the Federal Supreme Court to weigh Praefcke's constitutional rights against the Museum's own right to restrict access to its immovable and movable property.

Previous Supreme Court decisions have considered whether it is an unlawful impairment of property to make and exploit photographs of works without an owner's consent. ${ }^{60}$ These cases turned on the relationship between the physical ownership rights and the right to prevent the exploitation of photographs of that property. For immovable works, the Court held owners may regulate who enters their property and under what conditions. ${ }^{61}$ For movable works, like paintings, no

\footnotetext{
55 REM IV (c), para. 22.

${ }^{56} R E M I V(c)$, para. 26. Previous courts have held Sec. 72 Copyright Act does not extend to photographic reproductions of other photographs. German Federal Supreme Court, 8 November 1989, Case No. I ZR 14/88 669 (673) - Bibelreproduktion (technical photographic reproduction of copper engravings), available at https://de.wikisource.org/wiki/Bundesgerichtshof (Accessed 29 October 2019); Federal Supreme Court, 7 December 2000, Case No. I ZR 146/98 - Telefonkarte (technical reproduction of an existing graphic), available at https://doi.org/10.7328/jurpcb/2001168148. It is possible the Federal Supreme Court's application of Sec. 72 Copyright Act to photographs of public domain paintings undermines the EU's harmonisation of protection periods. The argument is that the Fedearl Supreme Court violated the Art. 101 Basic Law's right to a statutory judge by failing to refer the case. See, e.g. Federal Constitutional Court, October 6, 2017, Case No. 2 BvR 987/16, paras. 1-18.

57 REM IV (c), para. 26.

58 REM IV $(c)$, para. 26.

59 Wikimedia is currently preparing a constitutional appeal to the German Federal Constitutional Court (BverfG) for violating German Constitutional Law (Basic Law). Valie Djordjevic, "Mögliches Happy End dank neuem EU-Urheberrecht" (iRIGHTSinfo, 15 April 2019), available at https://perma.cc/W5KAWN6A.

60 German Federal Supreme Court, 20 September 1974, Case No. I ZR 99/73 - Schloss Tegel; German Federal Supreme Court, 17 December 2010, Case No. v. ZR 44/10 - Preußische Gärten und Parkanlagen I; German Federal Supreme Court, 1 March 2013, Case No. v. ZR 14/12 - Preußische Gärten und Parkanlagen II.

61 This extends to who may benefit economically from entering and photographing buildings or gardens onsite. This right is sustained by Sec. 1004(1) German Civil Code. German Federal Supreme Court, 1 March 2013, Case No. v. ZR 14/12 - Sanssouci II.
} 
Federal Supreme Court decision exists. ${ }^{62}$ The Court in REM IV(c) avoided this issue by granting injunctive relief via the photography ban, which required an examination of the ban's conditions. ${ }^{63}$ The Court reasoned the Museum had a legitimate interest in regulating visitor behaviour. ${ }^{64}$ This included photography prohibitions, which serve to protect artworks and visitors' privacy, to facilitate the proper running of the museum, and to honour other general obligations to lenders and the public. ${ }^{65}$

Praefcke argued the Museum's purpose must be interpreted in accordance with his constitutional rights, specifically the freedom of information in Art. 5(1) Basic Law and the social obligations of property ownership in Art. 14(2) Basic Law. ${ }^{66}$ Under this interpretation, heritage institutions must permit photography for private, scientific, and educational purposes. ${ }^{67}$ The Federal Supreme Court disagreed and held no fundamental rights were impaired. Instead, the Court found any public interest in not being prohibited from taking photographs in institutions falls outside those protections and, at most, might implicate the general freedom of action in Art. 2(1) Basic Law. ${ }^{68}$ Still, the Court found the Museum's ban complied with Art. 2(1) Basic Law because it was proportional to concerns around the artworks' protection and institutional operations, and because individual permits were granted. ${ }^{69}$

\subsection{Post-REM Caselaw Considerations}

At first glance, the REM Caselaw should be welcomed: it clarifies that photographic reproductions are not original. However, they are subject to the lesser protection, which raises cross-border reuse issues in Member States without "other photographs" protections. The effect of the second outcome is to vest absolute rights with institutions to decide whether to reproduce and communicate (or not) public domain artworks in public collections.

Questions also arise around the PSI Directive and documents made in the performance of a public task. ${ }^{70}$ The REM's General-Director specifically relied on the PSID when saying institutions are "expressly entitled to digitise cultural

\footnotetext{
${ }^{62}$ Hans Peter Wiesemann, Comment on REM IV(c), jurisPR-ITR 7/2019. While Sec. 59 Copyright Act provides for the freedom of panorama, collections that remain inside the building fall outside this exception.

63 Sec. 307(1) German Civil Code requires courts to review the content of T\&Cs. While the Federal Supreme Court reasoned they might constitute an inappropriate disadvantage pursuant to the Sec. 307(1) German Civil Code balancing test, there was nothing inappropriate in the terms. REM IV(c), para. 50.

64 REM IV (c), para. 55.

${ }^{65} R E M I V(c)$, para. 55. Given the freedom of panorama is inapplicable, third-parties are unable to legally photograph public domain artworks and communicate them to the public, if made in violation of a visitation contract. See Euler (2009), p. 461.

66 REM IV (c), para. 59-65.

67 Scholars argue that such prohibitions interfere with the maintenance of our cultural memory and the freedom of communication. Dreier (2019b), p. 272.

68 REM IV (c), para. 57.

69 REM IV $(c)$, para. 70.

70 Discussed in Sect. 4.
} 
holdings and determine whether copyright results," and charges are authorised by the "obvious" legislative intent that "cultural institutions themselves should contribute to recouping the immense costs of digitizing their holdings." 71 The REM is not concerned with only licensing benefits. ${ }^{72}$ Like many others, ${ }^{73}$ the Museum feels it holds a moral obligation to control how works are used to protect art and its history from derogatory treatment. ${ }^{74}$ This exposes an underlying stewardship tension: institutions use copyright (and related rights) to maintain interpretive sovereignty and prevent subjective misuse, for example, on "unsuitable merchandising articles." 75 While owners may disapprove of certain reuses, no legal grounds exist to support such prohibitions.

As discussed in Sect. 2, the technologies must also be considered. The Museum's images were made using analogue photography methods of $1992 .{ }^{76}$ Praefcke used combination of scanning and computer software to make the images available online. Consequently, we have multiple technologies involved during the capture, manipulation, storage, and dissemination of the artworks. It is possible that copyright might arise at some point, namely during post-production image manipulation. But it remains unclear in which layer of the reproduction (and for whom) copyright might subsist.

This example illustrates how owners could resist the purpose of Art. 14 DSMD through multiple measures. Until recently, visitor regulations prohibited onsite photography, but the policy has since changed to permit photography for personal use only. ${ }^{77}$ However, no policy exists online regarding copyright in digital material. Most images are of special exhibitions - works that typically are not owned by a museum - and clearly display copyright notifications. ${ }^{78}$ Even if Art. 14 prevents owners from enforcing the rights claimed in photographic reproductions, no part of the law includes positive obligations to allow onsite photography or release digital reproductions. In reality, owners are legally entitled to ban onsite photography, hold reproductions close, and license and restrict reuse through contract-based

\footnotetext{
71 Authors' own translation. See Reiss-Engelhorn-Museen, "Statement on the legal dispute of the ReissEngelhorn-Museums with Wikimedia” (Museumsbesuch Reiss-Engelhorn-Museen), available at https:// perma.cc/E2VK-R4F9.

72 "Wikimedia will Streit um Gemälde-Fotos aus Museum vor den BGH bringen" (MONOPOL MAGAZIN FÜR KUNST UND LEBEN, 2017), available at https://perma.cc/MC6Q-BXKG.

73 Tanner (2004), p. 30; Crews (2012), p. 817; Crews and Brown (2011), pp. 277-278.

74 The Museum complained that the misuse subverted the $€ 250$ licensing fee for internet usage on Wikipedia in addition to the commercial licensing fee normally negotiated with the retailer and that it appeared on string-bikini underwear.

75 Reiss-Engelhorn-Museen, "Statement on the legal dispute of the Reiss-Engelhorn-Museums with Wikimedia" (Museumsbesuch Reiss-Engelhorn-Museen), available at https://perma.cc/E2VK-R4F9.

76 Praefcke used digital methods to capture his images in 2007. Although Praefcke's copyright was not considered, it is worth noting the ban's practical effect is to grant the Museum third-party copyright in visitor photographs.

77 See Reiss-Engelhorn Museen, "Fragen rund um Ihren rem-Besuch" (Museumsbesuch ReissEngelhorn-Museen), available at https://perma.cc/6F3A-H4E4.

78 See, e.g. "Gallery, Egypt - Land of immortality exhibition” (Museumsbesuch Reiss-EngelhornMuseen), available at https://www.rem-mannheim.de/ausstellungen/bildergalerien/aegyptenbildergalerie/ (Accessed 21 August 2019).
} 
agreements and website T\&Cs. ${ }^{79}$ In effect, the REM Caselaw carries the potential to render Art. 14 DSMD empty of its promise. We now examine gaps in legal developments that might facilitate this approach.

\section{EU Developments and Wider Effects}

Recent EU measures intend to remedy legal uncertainty and carry a legislative and political history in support of open culture. Section 4 squares Art. 14 DSMD with relevant provisions from the 2006 Copyright Term Directive (CTD) and the 2019 PSID to ascertain how treatment of reproduction media might proceed.

\subsection{EU Policy in Support of Open Culture}

Article 14 DSMD is a culmination of EU policy promoting open culture as early as 2002. ${ }^{80}$ Since then, the European Commission has consistently underscored that public domain materials should remain in the public domain once digitised via various official documents and initiatives. These include: funding OpenGLAM (Galleries, Libraries, Archives, and Museums); ${ }^{81}$ the Communication of 11 August $2008{ }^{82}$ the launch of Europeana $(2008) ;{ }^{83}$ the Europeana Public Domain Charter (2010); ${ }^{84}$ and the Recommendation of 27 October 2011. ${ }^{85}$ Moreover, in 2019, the Commission announced in the adoption of two Creative Commons licences for all

\footnotetext{
79 Specht-Riemenschneider and Paschwitz argue Art. 14 DSMD impacts the permissibility of photography bans which may turn on a museum's public or private funding status. They also argue the burden of proof shifts: bans will be generally inadmissible unless sufficient circumstances warrant blanket prohibitions. Specht-Riemenschneider and Paschwitz (2020), p. 107.

80 Salzburg Research Forschungsgesellschaft Mbh, "The DigiCult Report: Technological Landscapes for Tomorrow's Cultural Economy: Unlocking the Value of Cultural Heritage" (2002), available at https:// perma.cc/82SN-LAUU.

81 OpenGLAM was funded by the European Commission and coordinated by the Open Knowledge Foundation.

82 Commission Communication of 11 August 2008 Europe's cultural heritage at the click of a mouse: progress on the digitisation and online accessibility of cultural material and digital preservation across the EU [SEC(08) 2372], p. 7, available at https://perma.cc/R4FX-3BVN. ("In this context, it is important to stress the importance of keeping public domain works accessible after a format shift. In other words, works in the public domain should stay there once digitised and made accessible through the internet.").

83 Europeana Collections, https://www.europeana.eu/portal/en, available at https://perma.cc/2UL8RX62.

84 Europeana, "The Europeana Public Domain Charter" (2010), available at https://perma.cc/S67UAYJB. ("No other intellectual property right must be used to reconstitute exclusivity over Public Domain material. The Public Domain is an integral element of the internal balance of the copyright system" which "must not be manipulated by attempts to reconstitute or obtain exclusive control via regulations that are external to copyright.").

85 Commission Recommendation of 27 October 2011 on the digitisation and online accessibility of cultural material and digital preservation (2011/711/EU), Recital 13, available at https://perma.cc/3AFPLVP3. ("In order to allow wide access to and use of public domain content, it is necessary to ensure that public domain content remains in the public domain once digitised.").
} 
publications: CC BY 4.0 for all content, and CC0 (Public Domain Dedication) for all raw data, metadata, and other comparable documents. ${ }^{86}$

Despite the Commission's consistent pro-open stance, reports on the 2011 Recommendation's implementation noted numerous obstacles to the release of materials. ${ }^{87}$ These included the fear of losing control, the use of public domain material to generate income, and technical issues, ${ }^{88}$ stressing that open collections were still "more the exception than the rule." 89 The most recent report signals a positive trend, but emphasised institutions continue to prohibit reuse for commercial purposes against the need to confront this persisting mindset around loss of income and control. ${ }^{90}$

These reports and other official policy documents consistently highlight the need for greater legal clarity around IPR in digitised material, including metadata and photographers' rights as paramount to harmonising access conditions around public domain materials. ${ }^{91}$ The 2019 DSMD framework thus aims to improve certainty in this area. ${ }^{92}$ Below, we map out gaps in the framework that might undermine harmonisation goals and pro-open culture objectives.

\subsection{Article 14 DSMD and IPR in Reproduction Media}

The revised framework for IPR in reproduction materials achieves minimum harmonisation on a narrow subject matter, giving Member States broad discretion during transposition. The full text reads:

\section{Article 14}

Works of visual art in the public domain

Member States shall provide that, when the term of protection of a work of visual art has expired, any material resulting from an act of reproduction of that work is not subject to copyright or related rights, unless the material resulting from that act of reproduction is original in the sense that it is the author's own intellectual creation. ${ }^{93}$

\footnotetext{
${ }^{86}$ Commission Decision of 22/02/2019 adopting Creative Commons as an open license under the European Commission's reuse policy, Arts. 1-2, available at https://perma.cc/PE8P-K5QJ.

87 See European Commission (2014); European Commission (2016a); European Commission (2018).

88 European Commission (2014), p. 23; European Commission (2018), p. 28.

89 European Commission (2014), p. 21; see also European Commission (2016a), p. 7.

90 European Commission (2018), p. 29.

91 European Commission (2014), p. 23; European Commission (2018), p. 28.

92 Directive (EU) 2019/790, Recital 2.

93 Directive (EU) 2019/790, Art. 14. Recital 53 also states: "The expiry of the term of protection of a work entails the entry of that work into the public domain and the expiry of the rights that Union copyright law provides in relation to that work. In the field of visual arts, the circulation of faithful reproductions of works in the public domain contributes to the access to and promotion of culture, and the access to cultural heritage. In the digital environment, the protection of such reproductions through copyright or related rights is inconsistent with the expiry of the copyright protection of works. In addition, differences between the national copyright laws governing the protection of such reproductions give rise to legal uncertainty and affect the cross-border dissemination of works of visual arts in the public domain. Certain reproductions of works of visual arts should, therefore, not be protected by copyright or related
} 
Article 14 broadly encompasses any material resulting from an act of reproduction. This includes not only photographic reproductions, but other outputs like 3D scanning, as well as any component parts, such as metadata or software. It also applies to anyone reproducing a work of visual art, including the general public and commercial organisations. Open access advocates have therefore embraced Art. 14 for formalising ongoing efforts to protect the public domain from privatisation.

Article 14 is narrow in other regards. Crucially, Art. 14 applies to only "works of visual art." Excluded are acts of reproduction around other public domain works, like textbooks, sheet music, film, maps, scientific or other technical drawings. The Directive neither defines "visual art" nor illustrates what reproduction media might qualify for copyright (or not) - only that the materials must satisfy the AOIC threshold. This latter ambiguity is also a strength. Rather than reduce Art. 14's effect to, for example, exclusively two-dimensional reproductions of two-dimensional works, the text envisions technological progress and mandates that only sufficiently original works should be protected. ${ }^{94}$

In this way, Art. 14's formalisation of the AOIC standard is consistent with EU copyright doctrine, rather than disruptive. ${ }^{95}$ The Directive accepts that copyright might arise and supports exploiting IPR meeting that threshold. ${ }^{96}$ The onus therefore remains on makers to evaluate whether an output carries a personal imprint or qualifies for unencumbered release.

Article 14's specific effect will be to remove reproduction media of "works of visual art" in the public domain from the scope of national laws with Art. 6 CTD "other photographs" protections. ${ }^{97}$ This is an important development. The application of this provision to reproduction media contradicts the Commission's agenda on protecting the public domain and enhancing the digital single market. ${ }^{98}$ Rather than harmonise the IPR standard, Art. 6 CTD enables a system of mutuallyexclusive protections incompatible with the rationale underlying the expiration of copyright and a work's transfer to the public domain. ${ }^{99}$ Article 14 therefore remedies this fragmentation - but only for reproduction media of "works of visual art" in the public domain in European States subject to the DSMD. ${ }^{100}$

\footnotetext{
Footnote 93 continued

rights. All of that should not prevent cultural heritage institutions from selling reproductions, such as postcards.".

94 Recital 3 refers to "rapid technological developments" in stating that legislation "needs to be futureproof so as not to restrict technological developments." Directive (EU) 790/2019, Recital 3.

95 Directive 2006/116/EC, Art. 6.

96 Recital 53 refers to "certain reproductions" (emphasis added) when mandating that no new rights are warranted unless the new work satisfies the AOIC standard. Directive (EU) 2019/790, Recital 53.

97 Member States must comply by 7 June 2021. Directive (EU) 2019/790, Art. 29. Until transposition, related rights may be claimed and enforced. Member States like Denmark, Finland, Sweden, Austria, Italy, and Spain recognise "other photographs" protections on different grounds defined by terms ranging from 15 to 50 years. Margoni (2014), pp. 61-62.

98 See Sect. 4.1.

99 Directive 2006/116/EC, Art. 6.

100 Reproduction media of in-copyright works are unaffected and remain unharmonised. European States like Norway and Iceland fall outside the scope of the DSMD and may continue to recognise related rights.
} 
We must now wait to see how transposition proceeds - and, namely, whether Member States transpose verbatim, extend the provision to cover all public domain works, or take no action at all. ${ }^{101}$ Variations in the text's transposition could reintroduce issues to cross-border exchange. National laws might control what constitutes a "work of visual art" differently among Member States. For example, in the UK, this might translate to "artistic works" as defined by national legislation and case law. ${ }^{102}$ In Germany, visual art will encompass only works premised upon aesthetic expression with no functional purpose (excluding works of architecture or applied art). ${ }^{103}$ Differences in national categorisations may subsequently undermine harmonisation aims. Moreover, imagine that Germany's transposition aligns with Art. 14's text, while the Netherlands extends its scope to "works in the public domain." In Germany, a photographic reproduction of an out-of-copyright map (i.e. not a work of visual art) could receive Sec. 72 Copyright Act protection; in the Netherlands, the same reproduction could remain in the public domain. Users will need to assess IPR based on information such as the location of the host institution or the work itself when digitised.

This critique extends to differences in 3D technologies. 3D models made by scans likely fail to attract copyright protection; by contrast, 3D models made by photogrammetry likely satisfy copyright. ${ }^{104}$ This is because Member States generally recognise copyright in photographic reproductions of $3 \mathrm{D}$ works, the process by which photogrammetry proceeds. ${ }^{105}$ Because there is no consistent EUwide treatment around semi-automated digitisation processes, owners may opt for photogrammetry over scanning to secure a copyright in the $3 \mathrm{D}$ model. ${ }^{106}$

Uncertainty also remains with copyright arising during post-production editing. As discussed, courts have been silent on creative scope using computer software to edit and enhance a digital file. Accordingly, owners might distinguish past cases focused on analogue photography from contemporary reproductions made with new technologies.

Some guidance on this has been issued in the UK. In November 2015, the Intellectual Property Office published a (non-binding) Copyright Notice that suggested copyright might arise if "specialist skills have been used to optimise detail, and/or the original image has been touched up to remove blemishes, stains or creases." 107 It goes on to cite the CJEU and the AOIC standard's legal effect in UK

\footnotetext{
101 For Member States without Art. 6 "other protection" legislation, it could be argued that transposition is unnecessary.

102 Sect. 4 "Artistic works." Copyright, Designs and Patents Act 1988, c. 48.

103 See Sec. 2(4) Copyright Act; Wandtke, Bullinger and Bullinger, 5th edn. 2019, UrhG § 2 para. 86.

104 Unlike 3D scanning, photogrammetry uses 2D digital photography to capture perspectives of an object from various coordinates and reconstructs the object using post-production software.

105 "Scenario 3 - Human-operated digitisation," (Out of Copyright: Determining the Copyright Status of Works), available at https://perma.cc/Z4CW-HWFH; Margoni (2014), pp. 51-53.

106 "Scenario 2 - Semi-automated digitisation," (Out of Copyright: Determining the Copyright Status of Works), available at https://perma.cc/2RSH-AVGF.

107 Intellectual Property Office, "Copyright Notice: Digital Images, Photographs and the Internet GOV.UK," p. 3, available at https://perma.cc/P6DW-FALF. The Notice considers whether "digitised copies of older images [are] protected by copyright" and suggests "[s]imply creating a copy of an image
} 
law, reasoning it is unlikely that a retouched digital reproduction can be considered original as "there will generally be minimal scope for a creator to exercise free and creative choices if their aim is to make a faithful reproduction of an existing work." 108 This would suggest basic digital manipulation - processed individually or in automated batches - to enhance colour, remove unwanted shadows, and so on, fails to satisfy the AOIC standard.

Copyright in photographic reproductions has also been discussed at national level. In September 2018, the House of Lords debated whether the question of copyright should be left with institutions or whether the government should intervene. ${ }^{109}$ Similar to the REM General-Director's comments, arguments conflated the issues by framing the decisions to claim copyright and license images as "operational matters," or internal policy decisions to be taken by institutions. ${ }^{110}$ Yet decisions to employ copyright-based business models are not operational matters if the law does not support copyright. Indeed, this is the legal interpretation increasingly held among UK scholars. ${ }^{111}$

The UK has since announced there are no immediate plans to implement the 2019 DSM and PSI Directives. ${ }^{112}$ Even so, they could have an informal impact on institutional IPR management as other institutions increasingly embrace open access and UK institutions act to compete digitally online. ${ }^{113}$

While Art. 14 envisions wider access, national transposition must clarify areas to provide legal certainty for IPR and the cross-border exchange of reproduction media.

\subsection{Impact of the PSI Directive on Article 14 DSMD Goals}

Setting copyright aside, owners may use other measures to restrict access to Art. 14 reproduction materials. Viewing this wider context enables us to understand the potential limits of Art. 14 DSMD.

\footnotetext{
Footnote 107 continued

won't result in a new copyright of the item," but notes there remains "a degree of uncertainty regarding whether copyright can exist in digitised copies of older images for which copyright has expired.".

108 Intellectual Property Office, "Copyright Notice: Digital Images, Photographs and the Internet GOV.UK,” p. 3, available at https://perma.cc/P6DW-FALF.

109 "Museums and Galleries: Copyright: Written question - HL2907" (UK Parliament, 11 April 2017), available at https://perma.cc/7WF6-4B8P.

110 "House of Lords Debate 12 September 2018 on the question of image fees charged by national museums and galleries" (UK Parliament, 12 September 2018), available at https://perma.cc/D44CH3NQ.

111 See Petri (2014); Bently et al. (2018) pp. 112-117; Ian Macquisten, "UK Museums Right to Charge Image Fees is Called into Question" (The Art Newspaper, 28 November 2017), available at https://perma. cc/XWK6-K57L.

112 Response by Chris Skidmore (Secretary of State of Business, Energy and Industrial Strategy) on 21 January 2020, UK Parliament.

113 How open data brings increased digital engagement is discussed in Verwayen et al. (2011); see also Joris Pekel, "Democratising the Rijksmuseum" (Europeana, 2014), available at https://perma.cc/5EQ6VNTY.
} 
Published on 20 June 2019, the Directive on Open Data and the Re-use of Public Sector Information ${ }^{114}$ replaces the 2003 PSI Directive as amended in 2013 to encompass public heritage institutions. ${ }^{115}$ According to the 2013 Directive, restoring the reuse of cultural and associated materials to its innovative potential was an impetus for bringing public heritage institutions within its scope. ${ }^{116}$ The 2019 PSID repeats these aims, ${ }^{117}$ framing information generated during a public task as "important primary material" for digital innovation. ${ }^{118}$

The PSID is concerned with the economic aspects of reuse, rather than access to information. ${ }^{119}$ The 2019 PSID highlights the "considerable differences" among Member States "which constitute barriers to bringing about the full economic potential of that key document resource." ${ }^{120}$ Consequently, Member States must encourage public sector bodies to produce and disseminate data based on the "principle of "open by design and by default"" 121 and are authorised to "go beyond the minimum requirements set out" to ensure access and reuse of all PSID documents. $^{122}$ At the same time, the PSID includes several exceptions and privileges for cultural heritage institutions that conflict with Art. 14 DSMD.

First, Art. 1(2)(c) states PSID provisions do not apply to "documents for which third parties hold intellectual property rights." ${ }^{23}$ Based on the uncertainties discussed, copyright might be claimed in the reproduction media made by third parties (like museum photographers). It is also unclear whether this extends to all copyrights initially created by third parties, even if they grant or assign rights to the cultural heritage institution. ${ }^{124}$ If so, there is an argument that such rights will exclude the documents from the PSID and national IP law will apply. ${ }^{125}$

\footnotetext{
114 Directive (EU) 2019/1024.

115 Directive 2003/98/EC of the European Parliament and of the Council of 17 November 2003 on the reuse of public sector information, OJ L 345, 31 December 2003, 90-96, amended by Directive 2013/37/EU of the European Parliament and of the Council of 26 June 2013.

116 Recital 15 states: "Libraries, museums and archives hold a significant amount of valuable public sector information resources, in particular since digitisation projects have multiplied the amount of digital public domain material. These cultural heritage collections and related metadata are a potential base for digital content products and services and have a huge potential for innovative reuse in sectors such as learning and tourism. Wider possibilities for re-using public cultural material should, inter alia, allow Union companies to exploit its potential and contribute to economic growth and job creation." Directive 2013/37/EU, Recital 15.

117 Directive (EU) 2019/1024, Recital 65

118 Directive (EU) 2019/1024, Recital 13

119 European Commission (2019).

120 Directive (EU) 2019/1024, Recital 15

121 Directive (EU) 2019/1024, Art. 5 (2).

122 Directive (EU) 2019/1024, Recitals 16 and 19. Recital 39 dictates Member States may formalise measures around lower charges or no charges at all.

123 Directive (EU) 2019/1024, Art. 1 (2)(c), Recital 55.

124 Wirtz (2016), p. 162; Fischer and Wirtz (2016), p. 274.

125 Dreier (2019a), pp. 417-420.
} 
The requirement to make information not only available, but also reusable for commercial or non-commercial purposes is another key element. ${ }^{126}$ Here, an important distinction must be made regarding commercial and non-commercial purposes versus commercial or non-commercial purposes. ${ }^{127}$ Article 3 of the English version adopts the latter use, which generates uncertainty around whether commercial use must be embraced by public sector bodies, both with regards to original and non-original materials. ${ }^{128}$ Prohibiting commercial use could contradict the Directive's stated goals and EU policy, perpetuating barriers to the reuse of public sector and publicly funded information. ${ }^{129}$ In the German version, the text reads commercial and non-commercial purposes, which introduces inconsistency to harmonisation goals.

Institutions are not without recourse when it comes to costs and revenue generation. Article 6 exempts institutions from providing documents for free ${ }^{130}$ and permits setting fees above marginal costs to support operations. ${ }^{131}$ These charges must be practical and reasonable and cannot exceed "the cost of collection, production, reproduction, dissemination, data storage, preservation and rights clearance ... with a reasonable return on investment" (ROI). ${ }^{132}$ Ideally, this will translate to more transparent service-based fees to recoup costs associated with the production, management, and provision of digital media, instead of opaque licensing fees to commercially exploit (invalid) IPR.

But Recital 38 suggests otherwise. For guidance on calculating a reasonable ROI, it recommends looking to the private sector. ${ }^{133}$ This raises a number of issues. First, this is already common practice, ${ }^{134}$ which installs in the public sector fee-modelling systems built upon creating monopolies over a scarce product to turn a commercial profit. Following implementation of Art. 14 DSMD, such systems are improper for non-original documents made with public funds during the performance of a public task. Second, the private sector is not bound by the PSID. Requests regarding fee calculations will likely go unanswered or lack the necessary information to satisfy transparency as envisioned by the Directive. Third, for documents in which copyright is valid, the Directive obligates institutions to "exercise their copyright in

\footnotetext{
126 Directive (EU) 2019/1024, Art. 3.

127 Directive (EU) 2019/1024, Art. 3.

128 See also Directive (EU) 2019/1024, Art. 2 (11).

129 Directive (EU) 2019/1024, Recital 3; Euler (2015), pp. 82-101.

130 Directive (EU) 2019/1024, Art. 6(2b) ("in order not to hinder their normal running"). According to a 2011 limited study on PSI Reuse, very few institutions rely on income from reuse to support their public task, but often find it essential to undertake future reuse and service development. Clapton et al. (2011), p. 1.

131 Directive (EU) 2019/1024, Recital 38.

132 Directive (EU) 2019/1024, Art. 6(3) and (5).

133 Directive (EU) 2019/1024, Recital 38.

134 The picture agency of the Prussian Cultural Heritage Foundation Berlin calculates prices according to fees used by Mittelstandsgemeinschaft FotoMarketing (Photo Marketing Association for Medium-Sized Businesses). "bpk-Bildagentur," available at https:/perma.cc/R7VG-J6G6; "Was ist die Mittelstandsgemeinschaft Foto-Marketing und welche Aufgaben hat sie?" (Bundesverband professioneller Bildanbieter, BVPA), available at https://perma.cc/RPK6-QNET.
} 
a way that facilitates re-use." ${ }^{135}$ Current licensing practices impede reuse. ${ }^{136}$ For instance, fees calculated using the British Museum Online Price Calculator ${ }^{137}$ range from $£ 25^{138}$ to $£ 1,107,{ }^{139}$ putting reuse out-of-range for many users, especially where multiple licences are required. ${ }^{140}$ The lower-quality images released under the Museum's CC BY-NC-SA 4.0 license are unsuitable for many meaningful reuse purposes.

The exceptions in Art. 12 "Exclusive Arrangements" raise additional concerns. The Directive recognises the importance of private partnerships and the need to grant exclusive rights, noting "a certain period of exclusivity might be necessary" to recoup investment. ${ }^{141}$ Recital 49 recommends it should "be limited to as short a time as possible in order to comply with the principle that public domain material should stay in the public domain once it is digitised." ${ }^{142}$ repeating the previous Commission positions on access to the public domain. ${ }^{143}$ Article 12(3) suggests a period no longer than ten years, subject to review, and requires arrangements to be transparent and made public. ${ }^{144}$ Institutions must receive free copies of the digital resources, which require publication upon the agreement's expiration. ${ }^{145}$

This provision is initially promising. According to the text, exclusive arrangements must be limited to the right to digitise cultural resources. ${ }^{146}$ Photographic reproductions and other non-original outputs produced during exclusive arrangements should not be encumbered by improper IPR claims. Yet it is unlikely that commercial image agencies, like Bridgeman Images, will desist with efforts to

135 Directive (EU) 2019/1024, Recital 54.
136 See Kathryn M Rudy, "The true costs of research and publishing” (Times Higher Education, 29 August 2019), available at https://perma.cc/3QB3-7B8U; see also Nancy Allen, "Art Museum Images and Scholarly Publishing" (2012), available at https://perma.cc/DTC3-4ZSE.

137 See British Museum Images, https://www.bmimages.com/ (Accessed 21 August 2019). Online Price Calculators are used by UK institutions, like Tate, National Gallery, and the Victoria and Albert Museum. 138 Usage: Scholarly publications; Media: Academic journal; Territory: World, multiple languages; Unit or Time Period: Up to 1 year; Placement: Inside; Size: Up to full page; Quantity: Up to 500.

139 Usage: Sales catalogues and direct marketing; Media: Sales catalogue and brochure; Territory: World, multiple languages; Unit or Time Period: Up to 1 year; Placement: Inside; Size: Up to full page; Quantity: 500,000 to 1,000,000.

140 Allen highlights licenses may be manageable in isolation, but most publications use multiple images from multiples sources. Allen (2012), p. 1. See also Hillary Ballon and Mariet Westerman, "Art History and its Publications in the Electronic Age" (2006), available at https://perma.cc/9XJW-4X76; Bielstein (2006).

141 Directive (EU) 2019/1024, Recital 49.

142 Directive (EU) 2019/1024, Recital 49 (emphasis added).

143 Commission Communication (2008), p. 5; Commission Recommendation (2011), Annex 1, 2. Nonexclusivity.

144 Directive (EU) 2019/1024, Art. 12. (Exclusive agreements "should be subject to review taking into account technical, financial and administrative changes in the environment since the arrangement was entered into.").

145 Directive (EU) 2019/1024, Art. 12(3).

146 Directive (EU) 2019/1024, Art. 12(3) ("an exclusive right relates to the digitisation of cultural resources") and Recital 49 ("The period of an exclusive right to digitise cultural resources should not in general exceed 10 years"). 
protect revenue sources. ${ }^{147}$ Ten years is also a long time in terms of technological advancement. Consider cultural heritage digitised in 2009 released today for public consumption. Many key technical standards, resolutions, formats, and software have moved on since 2009. In the same manner, the primary materials subject to Art. 12 agreements may be outdated for contemporary innovation purposes in ten years.

Even without IPR, access remains a separate issue. Article 14(4) exempts institutions from making high-value datasets available free of charge. ${ }^{148}$ This reinforces incentives to release lower-quality datasets while commercialising highvalue datasets. No obligation exists to make raw data available to the general public, who might edit or repurpose the output (and attract copyright) on their own.

Institutions remain able to merchandise and offer products for sale that incorporate documents subject to the PSI Directive. Recital 53 DSMD expressly reassures the sector that Art. 14 "should not prevent cultural heritage institutions from selling reproductions, such as postcards." ${ }^{149}$ Read together, the revised PSI and DSM Directives require Member States to place heritage institutions on equal footing with other sectors to contribute to economic growth and job creation. Rather than sustaining a monopoly around the exclusive exploitation of reproduction media, the Directives envision an even playing field.

\subsection{Wider Effects on Cross-Border Exchange in the Digital Single Market}

A few points remain regarding contract overreach, the dissemination of works of visual art, and Art. 17 DSMD.

First, while Recital 53 DSMD stresses that differences among national protections affect the cross-border exchange of reproductions of public domain artworks, ${ }^{150}$ IPR is not the only issue to consider. Onsite and online, T\&Cs can restrict use beyond what copyright would normally recognise. Accordingly, owners remain able to restrict access and reuse of public domain materials through rights based in contract and property law.

To some extent, the DSM Directive protects user rights from overreach. Article 7(1) renders unenforceable certain contractual provisions contrary to Arts. 3 ("Text and data mining for the purpose of scientific research"), 5 ("Use of works and other subject matter in digital and cross-border teaching activities"), and 6 ("Preservation of cultural heritage"). ${ }^{151}$ Previous drafts included Art. 14 (then Art. 5(1a)) within the scope of Art. 7 (then Art. 5(1b)). ${ }^{152}$ The final text does not. ${ }^{153}$ Despite this, Art. 7 protects the reuse of reproduction media subject to IPR claims from overreach for purposes such as text and data mining, teaching activities, and cultural heritage

\footnotetext{
${ }^{147}$ Discussed in Sect. 5.

148 Directive (EU) 2019/1024, Art. 14(4).

149 Directive (EU) 2019/790, Recital 53.

150 Directive (EU) 2019/790, Recital 53.

151 Directive (EU) 2019/1024, Art. 7 (1).

${ }^{152}$ For an earlier version of Art. 14 (then Art. 5 (1a)) within this scope (Art. 5 (1b)), see European Commission (2016b).

153 Directive (EU) 2019/790, Art. 7.
} 
preservation. ${ }^{154}$ Yet in countries with contract overreach formalised in copyright law, institutions already broadly prohibit reuse within website $\mathrm{T} \& \mathrm{Cs}$, including around online content in the public domain. ${ }^{155}$

The PSI Directive aims to minimise such activity. Recital 44 discourages setting conditions or restrictions while recognising some parameters may be justified in the public interest, such as when documents include personal data or should acknowledge the source. ${ }^{156}$ In such cases, conditions should be "objective, proportionate and non-discriminatory" and limited to the greatest possible extent. ${ }^{157}$

Questions arise around the enforceability of T\&Cs under contract law and property law. ${ }^{158}$ Outcomes are highly contextual, dependent upon the relevant legal framework, specific terms, and alleged violations. ${ }^{159}$ Moreover, terms may be difficult to enforce, especially against third parties not bound by the contract. Legal certainty therefore may erode as images circulate (and re-circulate) online.

To this point, Art. 14 should positively impact the circulation of photographic reproductions of visual artworks in the public domain. Faithful digital reproductions already exist online often in multiples under various copyright claims. ${ }^{160}$ In the EU, IPR can be assessed according to the source work captured, rather than any transparent claims asserted by the reproducer.

Finally, concerns arise with the Art. 17 DSMD "upload filter" regulation of photographic reproductions. ${ }^{161}$ Artificial Intelligence (AI) is ill-equipped to assess whether a reproduction meets the AOIC threshold, let alone whether rights exist in the underlying work. ${ }^{162}$ Where competing rights are claimed in similar reproductions, how might the upload filter navigate these claims? Embedded metadata can help, but that information must be accurate and machine readable. Given that copyright-free data (or robust exceptions) are needed to train $\mathrm{AI},{ }^{163}$ institutions might play a leading role in developing and releasing datasets to stimulate innovation in AI. ${ }^{164}$ This highlights the importance of the 2019 DSM and PSI Directives' implementation in this area.

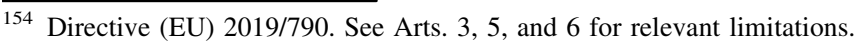

155 Such overreach is common among GLAM website terms in the UK. Wallace and Deazley (2016), pp. 3-4.

156 Directive (EU) 2019/1024, Recital 44.

157 Directive (EU) 2019/1024, Recital 44, Art. 8.

158 McBride (2016), pp. 307-314; REM IV(c), paras. 50-69.

159 Reuse violations will be assessed under national laws according to the source website (assuming it can be identified).

160 McCarthy and Wallace (2018).

161 Directive 2019/790/EU, Art. 17.

162 Spoerri (2019), pp. 182-183.

163 See Levendowski (2018).

164 The PSID cites AI as an advanced technology ripe for innovation using public sector information. Directive 2019/1024/EU, Recitals 3, 9, 10, and 13. See, e.g. "The Met x Microsoft x MIT," (Metropolitan Museum of Art), available at https://www.metmuseum.org/about-the-met/policies-and-documents/openaccess/met-microsoft-mit (Accessed 1 October 2019).
} 
Whether the combined impact will lead to greater transparency and fair competition in the internal market remains to be seen. We now examine transposition challenges and highlight areas of focus for implementation.

\section{The Case for National Transposition}

Despite how the EU legislation is transposed, Art. 14 will serve as a catalyst for open access. Section 5 maps out the potential for resistance and recommendations for national transposition and heritage institutions.

\subsection{The Potential for Resistance to Article 14 DSMD}

The text of Art. 14 is clear: no new rights unless the work satisfies the AOIC standard. But the question of what is legally sufficient to attract copyright may remain unresolved. This uncertainty has numerous consequences.

First, many actors have consistently advocated that decisions made during reproduction meet the AOIC standard. ${ }^{165}$ Article 14 presents no impediment for these actors; thus, the practice of making IPR claims in reproduction media will likely persist. ${ }^{166}$ This is especially true considering no negative consequences await those who continue to claim copyright, or what scholar Jason Mazzone coined as "copyfraud." 167

Second, as discussed in Sects. 2 and 3, case law provides imperfect guidance even for faithful photographic reproductions. REM Caselaw is binding only in Germany. Other jurisdictions remain free to disagree with or distinguish from the case. Copyright claims could continue under the premise the AOIC standard is met while owners neglect enforcement to avoid outcomes negating copyright in reproduction media. ${ }^{168}$ Aside from the REM, institutions seem unwilling to risk the reputational damage of a lawsuit; thus, the legal question of copyright will likely persist.

Third, owners can continue imposing conditions via website terms or photography bans. In fact, use of secondary restriction measures could rise, like installing paywalls, releasing low-quality datasets, removing online collections, or revising T\&Cs to be more restrictive. Owners might opt to use new technologies and editing software over basic reproduction methods to justify copyright. Claims that free and creative choices render the output a "certain reproduction" 169 under the AOIC

\footnotetext{
165 This was REM's position in all court proceedings.

166 This seems inevitable with reproductions made by new technologies. Section 3.3.

167 Mazzone (2005), p. 1026.

${ }^{168}$ Cameron argues claims to copyright chill user engagement, rendering lawsuits unnecessary: "If a false claim to copyright can bully potential authors away from using uncopyrightable reproductions of public domain images, no museum ever need pursue an infringement action, nor even acknowledge the Bridgeman decision. The threat alone may be enough to maintain control of the collection, as though valid copyright indeed subsisted in a museum's precise photographic reproductions of public domain paintings." Cameron (2006), p. 52.

169 Directive 2019/1024/EU, Recital 53.
} 
standard may be made and fortified in online T\&Cs. ${ }^{170}$ Even service-fee-based systems might restrict reuse through contractual terms. ${ }^{171}$ Sustained by contract and property law, these measures could subvert years of EU policy and the legislative intent underlying Art. 14.

Finally, the PSI Directive contains gaps that national implementation must fill, namely with exemptions in Art. 12 and Art. 14(4) around exclusive arrangements and releasing high-value datasets free of charge. ${ }^{172}$ Given that artwork reproductions comprise a significant source of revenue, there are major incentives for commercial picture agencies to resist Art. 14. Bridgeman I and II had no impact on the company's practices: Bridgeman Images continues to claim copyright and sign exclusive licensing arrangements worldwide. ${ }^{173}$ Just before publication of the DSM Directive, Bridgeman signed an agreement with the Italian Ministry of Culture to become the exclusive international picture agency for all 439 state-owned museums ${ }^{174}$ and another with the British Library to manage all commercial and editorial licensing in the UK. ${ }^{175}$

Lawmakers should be wary of attempts to block reform at national levels. Image organisations like CEPIC (Centre of the Picture Agency), ${ }^{176}$ BAPLA (British Association of Picture Libraries and Agencies), ${ }^{177}$ and SNAPIG (Syndicat des Agences d'Illustration Photographiques) ${ }^{178}$ lobbied strongly for IPR in the Directive's text. During its development, CEPIC published a press release expressing "extreme disappointment" at the "closed doors" development of Art.

\footnotetext{
170 The Museum of Fine Arts, Boston's website claims: "The Images depict objects from the MFA's collection in a manner expressing the scholarly and aesthetic views of the MFA. The Images are not simple reproductions of works and are protected by copyright." MFA, Boston, "Terms and Conditions" (Museum of Fine Arts, Boston, 11 October 2010), available at https://perma.cc/V4HR-P7NA. See also Crews (2012); pp. 821-822.

171 Photography bans are difficult to enforce, especially when the photographer is not the person who uploads or uses the image. Considering REM Caselaw, that assessment will be further complicated when photographs are made by international visitors and uploaded upon returning home.

172 Directive (EU) 2019/1024.

173 Bridgeman Images continues to claim overbroad rights in all content. "Bridgeman Copyright" (Bridgeman Images), available at https://perma.cc/NQ74-4K7Q.

174 Bridgeman has both acquired images and will reproduce works from all state-owned museums. BAPLA, "Important Announcement: Bridgeman signs agreement with MiBACT" (BAPLA, 19 April 2018), available at https://perma.cc/9EVQ-RKPV.

175 Bridgeman Images, "Announcement: British Library Appoints Bridgeman Images as its exclusive image licensing partner in the UK" (Bridgeman Images, 2016), available at https://perma.cc/YT49PSWL.

176 National associations, like BAPLA (UK) and SNAPIG (France) are also members of CEPIC. Individual members include Getty Images and Alamy. CEPIC, https://cepic.org/, available at https:// perma.cc/D66Z-5T7D.

177 Individual members include Bridgeman Images and picture libraries associated with many UK cultural heritage institutions, like the British Museum, British Library, Glasgow Life, Imperial War Museums, National Galleries Scotland, National Gallery of Ireland, National Gallery, National Museums Scotland, National Portrait Gallery, National Museums Liverpool, Oxford University, Tate, and the Victoria \& Albert Museum. BAPLA, https://bapla.org.uk/ (Accessed 21 August 2019).

178 Individual Members include Bridgeman Images, Leemage, La Collection, and Kharbine Tapabor. SNAPIG, https://www.snapig.com/ (Accessed 21 August 2019).
} 
14 with "no evidence as to the advantage to the larger public." ${ }^{179}$ CEPIC's efforts met with success in Switzerland in June 2019: after six years of lobbying, Switzerland will protect photographs irrespective of their "individual design." 180

Open access poses a threat to these business models. CEPIC and SNAPIG have publicly decried the movement, fearing "the direct and social repercussions of such upheavals would be particularly penalizing for the ecosystem of photographic agencies all over Europe." ${ }^{181}$ In France, the CGT-Culture Union issued a similar statement condemning open access as "an organized plunder of the images of our patrimony for purely private and commercial uses." ${ }^{182}$ While organisations may need to innovate, such alleged doom is unwarranted. Any decline in profit should reflect on inflexible or outdated business models rather than serve as evidence previous systems of exclusivity were necessary for sustainable digitisation. If commercial agencies with deep pockets and sophisticated technologies are successful in shaping attitudes around IPR and open access, the widespread benefits envisioned by the Directives may be reduced to collateral damage. ${ }^{183}$

By contrast, two counter examples of innovation (via exclusive and nonexclusive arrangements) illustrate the greater potential of commercial partnerships. First, a Van Gogh Museum and Fujifilm Belgium collaboration developed an innovative technique that combines a $3 \mathrm{D}$ scan with high-resolution images to produce (and sell) 3D-printed reproductions of Van Gogh paintings. ${ }^{184}$ A second collaboration between ING, Microsoft, and the Tu Delft and Mauritshuis Museums called The Next Rembrandt used digital technologies to analyse Rembrandt's paintings across four centuries; AI then generated a new 3D-printed Rembrandt painting. ${ }^{185}$ In addition to the basic and complex outputs, the IPR developed from these partnerships includes new patented technologies, branding, and software for commercial exploitation.

What seems particularly unjust is when an institution reuses its public domain collection for innovative commercial projects and restricts access by claiming IPR and charging for use of basic outputs, like raw data and high-resolution

\footnotetext{
179 BAPLA, "CEPIC Statement on Works of Visual Arts in the Public Domain" (BAPLA, 26 February 2019), available at https://perma.cc/FK5M-EU7J.

${ }^{180}$ See "Press Communication of the Schweizerische Arbeitsgemeinschaft der Bild-Agenturen und Archive" (SAB, 4 June 2019), available at https://perma.cc/L932-2A77.

181 "CEPIC supports SNAPIG against the Open Access project," (CEPIC, 13 June 2019), available at https://perma.cc/XA3F-RBWD.

182 "COMMUNIQUE DE PRESSE/Open data sur les images des musée et monuments: Non au pillage de notre patrimoine par Google," (CGT, October 2019), available at https://perma.cc/8MCG-6T9S.

183 The Prussian Cultural Heritage Foundation uses bpk-Bildagentur as its central commercial picture agency, applying a CC BY-NC-SA license to low-resolution images while commercialising highresolution images. See "Unser Angebot ist einfach einmalig!" (Stiftung Preußischer Kulturbesitz, 8 February 2019), available at https://perma.cc/DWN4-EUL6; "Online collections database" (SMB-digital), available at http://www.smb-digital.de/.

184 "Van Gogh Museum Edition Collection," (Van Gogh Museum), available at https://perma.cc/FU4XEW2R.

185 The Next Rembrandt, available at https://www.nextrembrandt.com (Accessed 21 August 2019).
} 
photographic reproductions, and imposes photography bans. ${ }^{186}$ In effect, the public becomes excluded from any meaningful innovation around the public domain. From an economic perspective, the public has paid to access the work during the copyright term, and for its preservation, reproduction(s), and continued maintenance by institutions. From a legal perspective, the public has paid for copyright development, consultation, and reform at international, EU, and national levels. It seems unfair that the public must pay to reuse non-original reproduction media of public domain works stewarded and digitised with public funds - and - to potentially foot that steward's bill when suing a user to secure exclusive rights to make, authorise, and commercialise reproductions of public domain artworks. Yet this is the exact scenario that played out in REM Caselaw. ${ }^{187}$ The following section highlights the necessary areas of focus to deter burdens around reuse of the public domain.

\subsection{Recommendations and Areas of Focus}

While the economic and more practical aspects will require national deliberation, Member States should acknowledge that the legal framework is currently stacked to incentivise exploiting public domain materials, rather than ensuring that open access is achieved. One obvious path towards rebalance is to increase government funding to support long-term digitization and open access goals, and, in the process, to establish positive obligations to release raw and non-original data. ${ }^{188}$ But institutions also have an important role to play. Below, we lay out a number of recommendations for Member States and heritage institutions.

\subsubsection{Member States}

Member States should broadly counter any resistance by providing the necessary legal teeth and transposing a public right to enforcement of Art. 14. This could be achieved via PSID provisions. Recitals 41-42 and Art. 4 envision an impartial process with means of redress to review negative decisions regarding access or high fees. ${ }^{189}$ This process could also assess the appropriateness of IPR. Member States should therefore dedicate resources and agency to a public review body to ensure the legislative intent behind the DSM and PSI Directives is realised.

Transposition must also clarify textual gaps. First, Member States should clearly outline the non-original status of faithful photographic reproductions and transpose the text to apply to all public domain works, rather than only "works of visual art" in the public domain. Communia recently published guidelines for two possible

\footnotetext{
186 The Van Gogh Museum reserves copyright; the Mauritshuis releases high-resolution images as public domain for any reuse purpose. See "Use and Permissions of Collection Images" (Van Gogh Museum), available at https://perma.cc/TFE4-QEDH; and "Request Visual Material" (Mauritshuis), available at https://www.mauritshuis.nl/en/explore/the-collection/request-visual-material/ (Accessed 1 October 2019).

187 In REM Caselaw, Mannheim represented the Museum; thus, the public was liable for legal fees if unsuccessful.

${ }^{188}$ See, e.g. Kapsalis (2016), pp. 5-9.

189 Directive 2019/1024/EU, Recital 41-42, Art. 4.
} 
scenarios: implementing the text as is, or going beyond the narrow scope of Art. 14. ${ }^{190}$ This guidance, in combination with ours, would help secure greater access to all public domain reproduction media. Second, when addressing the reuse of PSI documents and DSM reproduction media, transposition should eliminate ambiguities around "non-commercial or commercial use" by transposing texts as "noncommercial and commercial use." Third, transposition should safeguard Art. 14 by formalising contract override provisions that render void any overbroad rights claimed in T\&Cs. In doing so, Member States should reinforce the aims of Recital 44 and Art. 8 PSID to ensure any necessary restrictions are "objective, proportionate and non-discriminatory" to the greatest extent. Finally, related to this, Member States should clarify that photography bans cannot be misused to prevent the reproduction of public domain works for reasons other than legitimate interests, such as protecting the artworks and visitors' privacy or to facilitate the proper running of the institution.

EU legislation is designed to establish efficient measures for access to public domain heritage and reuse of non-original reproduction materials. Member States can informally encourage this in various ways, such as by following the Commission's lead on open data and adopting $\mathrm{CC} 0$ and $\mathrm{CC}$ BY at national levels. ${ }^{191}$ At the least, Member States should promote open-compliant policies ${ }^{192}$ and expressly discourage burdens like high fees and obstructive technical measures (e.g. watermarks or low-quality data). ${ }^{193}$

Member States can also support institutions redesigning fee-models to reflect charges for service rather than content in line with the PSI Directive. While ROI may be important to fund future initiatives, the PSID mandates charges must be made reasonable and transparent. ${ }^{194}$ Accordingly, transposition should formally require transparency around fees and ROI calculation. This would bring at least two benefits. First, publication will aid other institutions budgeting for digitisation and introduce competitive prices to those charged by closed private-sector business models. ${ }^{195}$ And, second, publication will help educate the public (and the government) about the costs associated with maintaining a digital collection.

\footnotetext{
190 "Our Guidelines for the Implementation of the DSM Directive," (COMMUNIA, 2 December 2019), available at https://perma.cc/YTT2-MHH7.

191 Discussed in Sect. 4.1.

192 To qualify as "open" under the Budapest Open Access Initiative, the Bethesda Statement on Open Access Publishing, the Berlin Declaration on Open Access to Knowledge in the Science and Humanities, and Open Knowledge Foundation, policies must allow reuse for any purpose, including commercial. Only GLAMs making materials available under Public Domain, CC0, CC BY, CC BY-SA, and "no known copyright restrictions" statements comply with international definitions. See Budapest Open Access Initiative, available at https://perma.cc/7RR7-D4YX; Bethesda Statement on Open Access Publishing, available at https://perma.cc/GHB7-9KUK; Berlin Declaration, available at https://perma.cc/RE7CCF6M; Open Definition, "Open Definition 2.1" (Open Content and Open Knowledge), available at https://perma.cc/B5KL-T8SS.

${ }^{193}$ Commission implementation reports stress such barriers should be eliminated. Discussed in Sect. 4.1.

194 Discussed in Sect. 4.3.

195 Article 14 applies only after copyright expires. Photo agencies may continue licensing reproductions of in-copyright artworks. The Article's broader effect might be to make competition and fee-modelling around these materials fairer and therefore more accessible to the public.
} 


\subsubsection{Cultural Heritage Institutions}

Regardless of how transposition proceeds, open access is likely inevitable for the cultural sector. ${ }^{196}$ Institutions should begin revising IPR policies rather waiting for DSMD and PSID consolidation. Should national legislation carry ambiguities, institutions could mitigate legal uncertainty by proactively adopting $\mathrm{CC} 0$ and $\mathrm{CC} \mathrm{BY}$ to facilitate innovation and the cross-border exchange of public domain cultural heritage.

Institutions are ideally placed to champion the open movement and enrich the commons with freely-licensed materials. ${ }^{197}$ This requires strengthening efforts to digitise collections and modernise open business models. One way is by assessing a project's components for its IPR value and releasing non-original and more basic outputs. At the very least, open-compliant licenses should be adopted to allow commercial reuse in line with the Commission's 2011 Recommendation and the PSID. Another way is to adopt service-fee-based models, which are more transparent and transfer costs to consumers during new digitisation. Institutions should explore fairer business models designed for users rather than commercial markets, and publish these new fee-models online. ${ }^{198}$

Technical aspects must also be considered. Despite the Art. 14(4) PSID exemption to make high-value datasets available free of charge, PSI documents and reproduction media should be released as machine-readable, high-quality data whenever possible. Making materials available with rich metadata and rights information enables innovative engagement and keeps cultural materials living in our collective cultural memory. ${ }^{199}$ This should include reducing technical burdens via open application programming interfaces (API) in standardised formats, as well as being transparent about how outputs are generated. ${ }^{200}$

A number of online platforms and cultural data aggregators exist to release content. Institutions might use systems developed by others, like Europeana, ${ }^{201}$ Wikimedia Commons, ${ }^{202}$ or $\mathrm{GitHub}^{203}$ to structure and host materials to avoid the expense of creating new platforms. This savings could extend to involving the public in digitization. Setting aside legitimate concerns around privacy and cultural sensitivity, institutions should allow visitor reproductions and cease treating photography requests as competition. ${ }^{204}$ Outcomes shared from these initiatives can

\footnotetext{
196 See Tanner (2016), pp. 239-247; Sanderhoff (2013), p. 143; Euler (2018), p. 73.

197 A number of institutions already do. Douglas McCarthy and Andrea Wallace, "Survey of open access policy and practice" (Google Sheets, 2018), http://bit.ly/OpenGLAMsurvey (Accessed 21 August 2019).

198 Institutions with copyright fee-models should note evidence that the revenue received is rarely worth the expenditure. See Tanner (2004), p. 40; Kelly (2013), pp. 4-5.

199 See, e.g., Heald (2014); Buccafusco and Heald (2013).

200 The public cannot know from looking at an image whether it is merely retouched or creative intellectual effort is expended.

201 Europeana Collections, https://www.europeana.eu/portal/en (Accessed 1 June 2020).

202 Wikimedia Commons, https://commons.wikimedia.org/wiki/Main_Page (Accessed 1 June 2020).

203 GitHub, https://github.com/ (Accessed 1 June 2020).

204 Grassroots initiatives like Wikipedia Loves Art engage visitors with material collections to generate images and publicly accessible knowledge for Wikipedia. "Wikipedia:Wikipedia Loves Art" (Wikipedia, 2016), available at https://perma.cc/7CVE-39T8.
} 
help other institutions attempting to tackle digitization and allow for the crosspollination of knowledge and expertise among the parties involved.

Finally, it is worth noting the PSID itself can be used as a tool for Art. 14 DSMD enforcement. Individuals inside and outside of the EU have successfully obtained reproduction media from German, UK, and French institutions through freedom of information requests. $^{205}$

Despite the unsettled state of the law, the open access movement has gained momentum in the GLAM sector, with a number of institutions taking proactive steps to release reproduction media for public reuse. ${ }^{206}$ Adopting such policies has enabled institutions to redirect labour to other operations, ${ }^{207}$ reach new audiences globally, ${ }^{208}$ and critically examine other questions arising around digitisation. ${ }^{209}$ Yet, to many, the steps toward openly sharing reproduction media are still seen as radical and controversial. ${ }^{210}$ The challenge is therefore for legal and cultural sectors to close these gaps together. Otherwise, the benefits envisioned by the DSM and PSI Directives will be compromised by sustained efforts to privatize cultural heritage materials through improper IPR claims. ${ }^{211}$

\section{Conclusion}

Despite recent EU developments, the risk remains that a combination of property, contract, and (improper) IPR claims can be used to exclude the public from accessing and using both material and digital cultural heritage in the public domain. Advancements in reproduction technologies have significantly reduced the scope and latitude of individual decisions necessary to produce faithful reproductions of cultural heritage. Processes can be dictated by technical factors, such as the reproduction method, technology, or technique used, as well as by industry standards, institutional policies, and best practices. What once required creative skills, is now a more straightforward and technical process. The more digitization

\footnotetext{
205 US-based artist Cosmo Wenman used FOI legislation to obtain a 3D scan of the Nefertiti bust made by the Neues Museum (Berlin). Hakim Bishara, "Official 3D Scans of Nefertiti Bust Are Released After Three-Year Battle," (Hyperallergic, 29 November 2019), available at https://hyperallergic.com/530400/ official-3d-scans-of-nefertiti-bust-are-released-after-three-year-battle/ (Accessed 1 December 2019). Wenman is currently seeking enforcement of an FOI request to Musée Rodin. "Rodin's Thinker 3D Scan Access Effort," (Cosmo Wenman, 24 June 2019), available at https://cosmowenman.com/ BMAMuseeRodinThinker3DScan/ (Accessed 13 November 2019).

206 At the time of this writing, that number includes 738 GLAM institutions globally. See McCarthy and Wallace (2018).

207 Kelly (2013), p. 9.

208 Schmidt (2017), p. 32.

209 Open access may not be culturally appropriate. Pavis and Wallace (2019), pp. 118-119; (2020), pp. 7-8. This questioning extends to the politics embedded in mass digitisation projects, our understanding of postcolonial digital heritage and its potential, and the sustainability of digitization initiatives. See Thylstrup (2018); see also Risam (2018).

210 Sanderhoff (2013), p. 134.

211 See, e.g. Pessach (2008).
} 
proceeds under these pre-determined technical conditions, the less the possibility for the reproduction to diverge from a given set of parameters and attract new IPR.

Legal frameworks have yet to account for this change. Accordingly, a number of ambiguities must be confronted to ensure important primary materials are made available for digital innovation and knowledge generation. First, lawmakers must transpose Art. 14 of the DSM Directive to broadly encompass all public domain works and clearly discourage claiming IPR in non-original, basic reproduction media. Second, during transposition of the PSI Directive, lawmakers must close the gaps that enable cultural heritage institutions to reserve reproduction media for their own private commercialization purposes and limit public access and reuse via overbroad policies. Finally, lawmakers must consider the REM Caselaw decision and discourage ancillary restrictive measures by introducing positive obligations to extend appropriate access and by establishing a public right to enforcement of Art. 14 DSMD via the PSID.

Open Access This article is licensed under a Creative Commons Attribution 4.0 International License, which permits use, sharing, adaptation, distribution and reproduction in any medium or format, as long as you give appropriate credit to the original author(s) and the source, provide a link to the Creative Commons licence, and indicate if changes were made. The images or other third party material in this article are included in the article's Creative Commons licence, unless indicated otherwise in a credit line to the material. If material is not included in the article's Creative Commons licence and your intended use is not permitted by statutory regulation or exceeds the permitted use, you will need to obtain permission directly from the copyright holder. To view a copy of this licence, visit http:// creativecommons.org/licenses/by/4.0/.

\section{References}

Bently L, Sherman B, Ganjgee D, Johnson P (2018) Intellectual property law. Oxford University Press, Oxford

Bielstein SM (2006) Permissions, a survival guide: blunt talk about art as intellectual property. University of Chicago Press, Chicago

Buccafusco CJ, Heald PJ (2013) Do bad things happen when works enter the public domain?: Empirical tests of copyright term extension. Berkeley Technol Law J 28(1):1-43

Butler KC (1998) Keeping the world safe from naked-chicks-in-art refrigerator magnets: the plot to control art images in the public domain through copyrights in photographic and digital reproductions. Hastings Commun Entertain Law J 21:55-127

Cameron CT (2006) In defiance of Bridgeman: claiming copyright in photographic reproductions of public domain works. Texas IP Law J 15:31-60

Clapton G, Hammond M, Poole N (2011) PSI re-use in the cultural sector: final report. Curtis + Cartwright. Available at: https://perma.cc/K68J-PRMH

Crews KD (2012) Museum policies and art images: conflicting objectives and copyright overreaching. Fordham IP Media Entertain Law J 22:795-832

Crews KD, Brown MA (2011) Control of museum art images: the reach and limits of copyright and licensing. In: Kur A, Mizaras V (eds) The structure of intellectual property law: can one size fit all?. Edward Elgar, Cheltenham

Deazley R (2001) Photographing paintings in the public domain: a response to Garnett. Eur IP Rev 23(4): 179-184

Dreier T (2019) Anmerkung zu BGH Museumsfotos: Lichtbildschutz von Reproduktionsfotografien gemeinfreier Werke - vertragliche Fotografierverbote in Museen. Juristenzeitung 417-420

Dreier T (2019b) Bild und Recht - Versuch einer programmatischen Grundlegung. Nomos, Baden-Baden

Euler E (2009) Recht am Bild der eigenen Sache?: Wie frei sind gemeinfreie Kulturgüter. AFP 5(40):459-464. https://doi.org/10.17176/20180716-142233-0 
Euler E (2015) Open access: Verpflichtung oder Geschäftsmodell für Kultureinrichtungen?! In: Euler E, Hagedorn-Saupe M, Maier G, Schweibenz W, Sieglerschmidt J (eds) Kulturportale im Internet. DeGruyter, Berlin. https://doi.org/10.1515/9783110405774-008

Euler E (2018) Open access, open data und open science als wesentliche Pfeiler einer (nachhaltig) erfolgreichen digitalen transformation der Kulturerbeeinrichtungen und des Kulturbetriebes. In: Pöllmann L, Herrmann C (eds) Der digitale Kulturbetrieb. Strategien, Handlungsfelder und Best Practices. Springer, Wiesbaden

European Commission (2014) European Commission's report on digitisation, online accessibility and digital preservation of cultural material. Report on the implementation of commission recommendation 2011/711/EU 2011-2013. Available at: https://perma.cc/8MTV-QPNZ

European Commission (2016a) Cultural heritage: digitisation, online accessibility and digital preservation. report on the implementation of commission recommendation 2011/711/EU 2013-2015. Available at: https://perma.cc/2BKB-EEBQ

European Commission (2016b) Proposal for a directive of the European parliament and of the council on copyright in the digital single market - COM/2016/0593. Available at: https://perma.cc/4FDYQMWR

European Commission (2018) Cultural heritage: digitisation, online accessibility and digital preservation. consolidated report on the implementation of commission recommendation 2011/711/EU 2015-2017. Available at: https://perma.cc/Y2WV-NBP6

European Commission (2019) European legislation on open data and the re-use of public sector information. Available at: https://perma.cc/M2VR-2BYZ

Fischer V, Wirtz H (2016) Auswirkungen der Einbeziehung in den Anwendungsbereich der PSIRichtlinie am Beispiel der Museen. In: Dreier T, Fischer V, van Raay A, Spiecker I (eds) Informationen der öffentlichen Hand - Zugnag und Nutzung. Nomos, Baden-Baden

Garnett K (2000) Case comment: copyright in photographs. Eur IP Rev 22(5):229-237

Gervais DJ (2002) Feist goes global: a comparative analysis of the notion of originality in copyright law. J Copyr Soc USA 49:949-981

Hamma K (2005) Public domain art in an age of easier mechanical reproducibility. D-Lib Mag 11(11):11-15

Heald PJ (2014) How copyright keeps works disappeared. J Empir Legal Stud 44:829-866

Kapsalis E (2016) The impact of open access on galleries, libraries, museums, \& archives. Smithsonian Institutes. Available at: https://perma.cc/6HNA-2CXX

Katyal S (2017) Technoheritage. Calif Law Rev 105:1111-1172

Kelly K (2013) Images of works of art in museum collections: the experience of open access. Council on Library and Information Resources. Available at: https://perma.cc/B6RT-49CU

Levendowski A (2018) How copyright law can fix artificial intelligence's implicit bias problem. Wash Law Rev 93:579-630

Margoni T (2014) The digitisation of cultural heritage: originality, derivative works and (non) original photographs. Institute for Information Law (IViR) ID 2573104. Available at: https://perma.cc/ EV96-6XT9

Margoni T (2016) The harmonisation of EU copyright law: the originality standard. In: Perry M (ed) Global governance of intellectual property in the 21st century. Springer, Berlin

McCarthy D, Wallace A (2018) Survey of open access policy and practice. Available at: http://bit.ly/ OpenGLAMsurvey

Mazzone J (2005) Copyfraud. NYU Law Rev 81:1026-1100

McBride P (2016) Cultural institutions and website use restrictions: contract or no contract? In: Wallace A, Deazley R (eds) Display at your own risk: an experimental exhibition of digital cultural heritage. CREATe, Brighton

Pavis M, Wallace A (2019) Response to the 2018 Sarr-Savoy report: statement on intellectual property rights and open access relevant to the digitization and restitution of African cultural heritage and associated materials. JIPITEC 10(2):240-271

Pavis M, Wallace A (2020) SCuLE response for the EMRIP report on repatriation of ceremonial objects and human remains under the UN declaration on the rights of indigenous peoples. Available at: https://zenodo.org/record/3760293

Pessach G (2008) [Networked] Memory institutions: social remembering, privatization and its discontents. Cardozo Arts Entertain Law J 26:71-129

Petri G (2014) The public domain vs. the museum: the limits of copyright and reproductions of twodimensional works of art. J Conserv Mus Stud 12(1):1-12 
Peukert A (2012) Die Gemeinfreiheit. Begriff, Funktion, Dogmatik. Mohr Siebeck, Tübingen

Rahmatian A (2013) Originality in UK copyright law: the old 'skill and labour' doctrine under pressure. Int Rev IP Compet Law 44:4-34

Risam R (2018) New digital worlds: postcolonial digital humanities in theory, praxis, and pedagogy. Northwestern University Press, Chicago

Sanderhoff M (2013) Open images: risk or opportunity for art collections in the digital age? Nord Museulogi 2:131-146

Schmidt A (2017) MKG collection online: the potential of open museum collections. KJK 7:25-39

Specht-Riemenschneider L, Paschwitz J (2020) Gemeinfreiheit als Prinzip. Reichweite und Umsetzungsbedarf des Art. 14 DSM-Richtlinie. In: RuZ, Jahrgang 1, Heft 1. Available at: https://doi.org/ $10.5771 / 2699-1284-2020-1$

Spoerri T (2019) On upload-filters and other competitive advantages for Big Tech Companies under Article 17 of the directive on copyright in the digital single market. JIPITEC 10(2):173-186

Stokes S (2001) Photographing paintings in the public domain; a response to Garnett. Eur IP Rev 23(7):354

Stokes S (2002) Graves' case and copyright in photographs: Bridgeman v. Corel. In: McClean D, Schubert K (eds) Dear images: art, copyright and culture. Ridinghouse, London

Tanner S (2004) Reproduction charging models \& rights for policy digital images in American art museums. Andrew W Mellon Foundation, New York

Tanner S (2016) Open GLAM: the rewards (and some risks) of digital sharing for the public good. In: Wallace A, Deazley R (eds) Display at your own risk: an experimental exhibition of digital cultural heritage. CREATe, Brighton

Thylstrup NB (2018) The politics of mass digitisation. MIT Press, Cambridge

Verwayen H, Abrikdys M, Kaufman P (2011) The problem with the yellow milkmaid: a business model perspective on open metadata. Europeana. Available at https://perma.cc/48RH-5YBS

von Welck K (ed) (1992) Sammelleidenschaft Mäzenatentum und Kunstförderung. Von den Kurfürsten zum Land Baden-Württemberg. Kostbarkeiten aus dem Museum für Kunst-, Stadt- und Theatergeschichte im Reiß-Museum der Stadt Mannheim. Braus, Heidelberg

Wallace A (2016) Exhibition methodology. In: Wallace A, Deazley R (eds) Display at your own risk: an experimental exhibition of digital cultural heritage. CREATe, Brighton

Wallace A (2019) Mona Lisa. In: Op den Kamp C, Hunter D (eds) A history of intellectual property in 50 objects. Cambridge University Press, Cambridge

Wallace A, Deazley R (eds) (2016) Display at your own risk: an experimental exhibition of digital cultural heritage. CREATe, Glasgow

Wienand P, Booy A, Fry R (2000) A guide to copyright for museums and galleries. Routledge, Abingdon

Wirtz H (2016) Die Kommerzialisierung kultureller Informationen der öffentlichen Hand. Dunker \& Humboldt, Berlin

Young A (ed) (2019) Rights and reproductions: the handbook for cultural institutions, 2nd edn. Rowman \& Littlefield, Lanham

Publisher's Note Springer Nature remains neutral with regard to jurisdictional claims in published maps and institutional affiliations. 